\title{
AN EMPIRICAL STUDY: CHARACTERISTICS OF BUSINESS ENTITIES AND CORPORATE GOVERNANCE ON RISK DISCLOSURE PRACTICES
}

\author{
Arfan AMRIN \\ Sekolah Tinggi Ilmu Ekonomi Muhammadiyah Palopo, Jend. Sudirman Street km. 3, \\ Binturu, South Wara, Palopo, Indonesia \\ E-mails:arfan_amrin@stiem.ac.id; amrin.arfan021090@gmail.com
}

Received 04 October 2018; accepted 27 December 2018

\begin{abstract}
This paper investigates the association between the characteristics of business entities, corporate governance, and practices of risk disclosure. Notably, the objective of this paper is to examine the impact of the characteristics of business entities and corporate governance on risk disclosure in non-financial companies. The samples used in this study included 312 non-financial companies registered on the Indonesia Stock Exchange. The hypothesis testing in this paper using regression analysis. The results of this paper indicate that the size of the audit committee (SAC), the availability of risk monitoring or risk management committees (RMC) and the quality of external auditors (AUD) are significantly associated with corporate risk disclosure practices (CRD). These empirical results show that the presence of risk monitoring committee, the quality of external auditors, and the size of the audit committee are the main factors determining the extent of risk disclosure, especially for non-financial companies listed on the Indonesia Stock Exchange. This paper also shows that the age of business entities has a negative impact on corporate risk disclosure practices.
\end{abstract}

Keywords: characteristics, business entity, corporate governance, risk disclosure, non-financial companies.

JEL Classification: M21, M40, M41.

\section{Introduction}

Every company cannot be separated from the existence of a risk which becomes the attention of stakeholders to avoid accounting fraud. The occurrence of accounting frauds has caused investors as interested parties lose confidence in the credibility of the information issued by the companies. The company must be able to do decent management to avoid the occurrence of loss. In an effort, a company faced to maintain the growth and developing transparency to disclose information. Disclosure of information in an open and honest in all things can influence user trust information on performance management of a company. Risk disclosure within the company is one of the essential parts for companies that conduct risk control or management. Dobler (2008) stated that the company disclosure is so substantial, especially in the nonfinancial sector companies. Therefore, required the implementation of good corporate governance by doing the process include identification, evaluation, and control of the risks being faced and conducts oversight of the risk management process so that uncertainties can be suppressed at the lowest level that can be accepted by the company. The topic of risk disclosure in Indonesia has developed since the promulgation of the Bank Indonesia Regulation No.8/4/PBI/2006 concerning The Practice of Good Corporate Governance. Monks and Minow (2011) stated that corporate governance describes the relationships of company parties to run the task in determining the direction and performance.

The study of risk disclosure has recently become a topic of particular concern in the accounting literature. This topic attracted the attention of investors because of fraudulent cases of large companies such as Enron and Worldcom

Copyright $\odot 2019$ The Authors. Published by VGTU Press.

This is an Open Access article distributed under the terms of the Creative Commons Attribution License (http://creativecommons.org/licenses/by/4.0/), which permits unrestricted use, distribution, and reproduction in any medium, provided the original author and source are credited.. 
(Oorschoot in Suhardjanto 2011). Even regulators and professional bodies have paid attention to risk disclosure practices by introducing guidelines and regulations to encourage companies to disclose risk information. Risk information is a substantive component of management comments that is useful for investors in decision making as described in IFRS (IFRS 2010). If an investor fails to identify the crucial actual risk factors of the company, investors cannot assess the correct level of risk of these companies. So that causes investors to make the wrong investment decisions that can end up in significant losses or disasters for investors (Abdullah et al. 2015).

Risk disclosure is one part of the declaration of qualitative information listed in the Notes to Financial Statements. Improvements in risk disclosure have even become an essential part of corporate governance reform (Madrigal et al. 2015) due to increasing business complexity and changes in the business context that have created uncertainty for the company's sustainability in the future (Abid and Shaiq 2015). Risk information can help reduce capital costs and allow companies to describe their awareness to manage these risks (Linsley and Shrives 2006). Risk disclosure is also one of the essential aspects of implementing risk management because it helps users of financial statements to assess current and future risks (Abraham and Cox 2007, Miihkinen 2013). Besides, it can help in the process of making investment decisions by evaluating information disclosed by the company; and increasing accountability for its impact on management (stewardship), investor protection and the usefulness of financial reporting (Elzahar and Hussainey 2012). So that when a financial crisis occurs, the main focus of attention is directed at the interests and problems related to risk reporting.

Amid the increasing need for disclosure of risk information and the benefits of disclosure, it has motivated previous research to study the relationship between general company characteristics and risk disclosure. Bamber et al. showed that a supervisor, head of the department with a background in financial (economic) and accounting education make more appropriate disclosures. Said et al. (2013) found that there was a significant relationship between the background of the CEO and the level of environmental disclosure. The variable of the audit committee size has a significant positive impact on exposure (Li et al. 2008, Li et al. 2012, Madi et al. 2014); does not affect risk disclosure (Elzahar and Hussainey 2012). The frequencies of audit committee meetings (MAC) has positively significantly related to the extent of corporate disclosure (Li et al. 2008, Li et al. 2012, Taliyang and Jusop 2011, Ettredge et al. 2011, Allegrini and Greco 2013, Talpur et al. 2018). Al-Maghzom et al. (2016) also show that audit committee meetings more often motivate banks to disclose more risk information. Research results (Meizaroh and Lucyanda 2011) showed that the availability of the risk management committee related to corporate risk disclosure and had a significant effect on risk management disclosures (Buckby et al. 2015). Types of auditors significantly associated to risk disclosure (Oliveira et al. 2011, Lopes and Rodrigues 2007, Mokhtar and Mellett 2013, Abid and Shaiq 2015, Carmona et al. 2016, Elshandidy and Neri 2015); no significant (Al-Mutawaa and Hewaidy 2010) with the disclosure. Status of ownership associated to risk disclosure (Meizaroh and Lucyanda 2011, Abraham and Cox 2007); voluntary disclosure (Gunawan and Susanto 2004); disclosure of intellectual capital (White et al. 2007); social responsibility disclosure (Siregar and Bachtiar 2010). Other studies indicated there is no influence of ownership status on corporate risk disclosure (Elzahar and Hussainey 2012, Probohudono et al. 2013) voluntary disclosure (Allegrini and Greco 2013).

Some studies showed a significant positive correlation between business entity age and compulsory disclosure (Owusu-Ansah and Yeoh 2005, Owusu-Ansah 1998, AlShammari et al. 2008); voluntary disclosure (White et al. 2007); there is no significant correlation between business entity age and corporate exposure (Bukh et al. 2005, AlMutawaa and Hewaidy 2010, Talpur et al. 2018). The level of risk significantly associated with risk disclosure (Hassan 2009, Probohudono et al. 2013, Oliveira et al. 2011); intellectual capital disclosure (White et al. 2007); not significantly associated with social responsibility disclosure (Siregar and Bachtiar 2010). This paper investigates the association between the characteristics of the business entity, corporate governance, and practices of risk disclosure. The risk model in this paper based on a model developed by the Institute of Chartered Accountants in England and Wales (ICAEW) which is also used by previous researchers (Mokhtar and Mellett 2013, Miihkinen 2013).

The occurrence of information asymmetry and the importance of risk disclosure in financial reporting, encourage researchers to conduct this research. Besides, risk disclosure is still an under-researched area despite the high demand from investors and shareholders for risk management disclosures. Also, the findings show a positive trend in the development of risk disclosure practices in Malaysia from 2001 to 2011 are insufficient and must be improved (Zadeh et al. 2016). Previous researchers have examined the relationship between corporate governance and risk disclosure. However, the results of his research are still diverse (inconsistent). Companies in their activities have risks and face different dangers so that exposure to information risk also tends to vary or differ. Therefore this researcher fills these gaps.

This research contributes to providing theoretical benefits as literature in explaining the relationship between corporate governance, company characteristics, and the level of risk disclosure that can provide ideas or ideas for academics to conduct further research. Policy contributions for users 
of accounting information can be used as consideration in making investment decisions or giving credit to companies, especially those that carry out risk reporting and as information to implement sound and good corporate governance.

The remainder of this paper then provides an overview of relevant company risk disclosure literature; theoretical arguments and development of research hypotheses; comprehensive research design to answer research questions, the results of applying this design are presented and conclude with conclusions and suggestions.

\section{Literature review and hypotheses development}

Agency theory states that if there is a disjunction between two parties, owners and managers as the principal and as an agent, then it would create the agency problems because each side will always try to maximize the function of their utility (Jensen and Meckling 1976). This theory in the implementation of risk disclosure was able to explain the submission of reliable information about the risks by managers to users of accounting information. Morris (1987) stated that the signaling theory related to asymmetric information in markets. Besides that, the signaling approach to the practice of risk disclosure describes the activities of company managers disclose risk information, including the owner of the company. Risk disclosure is an essential practice in the company to reduce the external costs of the company (Linsley and Shrives 2006) and help users of financial statements to assess the current or the future risks in order optimize revenue (Abraham and Cox 2007). The regulation that requires disclosing information risk as follows: 1) SFAS No. 60 (Revision 2016); 2) Decision of Chairman of the Indonesian Regulatory Authority for the Indonesian of Financial Statement No. KEP-431/BL/2012; and 3) Bank Indonesia regulations No. 14/14/PBI/2012.

Corporate governance is accountability for how to manage and control the company with a healthy and tasty. The corporate governance mechanism is essential in monitoring the company and harmonizing the interests of managers and shareholders in the capital market (Chakraborty et al. 2018). Choi and Meek (2011) told that corporate governance is a relationship between the management, the board of commissioners, directors, investors, and stakeholders who did the arrangements and guidance in carrying out the business activities of the company. Corporate governance is expected to prevent the manager from doing the cheating and being able to repair the achievement of the company. Ararat et al. (2010) stated that the diversity of directors illustrates the difference between the board of directors with respect to the attribute that can explain the difference in attitude and opinion; cause a variety of cognitive styles, thus enriching knowledge, wisdom, ideas, while Williams and O'Reilly (1998) stated that approaches for company boards would ultimately improve the quality of decision-making.
The board of commissioners formed a committee to help out the implementation of its work, including the audit committee that gives a view of the problem of accounting, financial reporting and the internal oversight system, the explanation as well as the independent auditor (Egon in FCGI 2000). Evaluate on a regular basis can support the development of an enterprise. One of the evaluations conducted in a company is an audit by the auditor. Subramaniam et al. argued that the auditor is a key to external oversight mechanism of the organizations and being the center of attention in particular risk management. Disclosure is a means of accountability in various fields. The quality of accounting information is closely related to the level of disclosure and is also influenced by the characteristics of a business entity. Elzahar and Hussainey (2012) showed that the firm characteristics were affecting the risk disclosure. It so important for foreign investors to conduct an assessment of the prospects in the long term (DiMaggio and Powell 1983). Corporate climate change can lead to the emergence of real risks and damage to the investment portfolio so that investors need risk information to consider the impact of information on their investment (Krishnamurti and Velayutham 2018).

The educational background/qualification of president director and corporate risk disclosure

Wallace and Coocke (1990) stated that the board of directors with accounting education and business would likely conduct a more extensive disclosure level because they are more aware of their business. Expertise is a significant predictor in the risk management disclosure model (Buckby et al. 2015). Bamber et al. (2010) showed that managers or head of a department with educational of financial and accounting background do more precisely disclosure. The best educational background of a manager within a company can be an essential factor in the practice of the disclosure (Said et al. 2018) and found that there was a significant relationship between the background of the $\mathrm{CEO}$ and the level of environmental disclosure (Said et al. 2013). Haniffa and Cooke (2002) explained that the educational experience does not affect the exposure. Based on the description and study of previous findings above, the hypothesis in this paper is as follows:

H1: Educational background or qualification of president director positively associated with corporate risk disclosure.

\subsection{Size of the audit committee and corporate risk disclosure}

The existence of an audit committee is significant in increasing the value of annual reports and reducing information asymmetry (Talpur et al. 2018) and is part of the internal control system in corporate governance (Al-Maghzom et al. 2016). Cotter and Silvester (2008) stated the supervisory function is not only crucial in the structure and 
composition of the council, but also for committees of business entity, especially in decision making. More the number of audit committee members, the company will improve the information disclosure (Ho and Wong 2001). The results of the prior study showed that the size of the audit committee has a significant positive effect on disclosure (Li et al. 2012, Li et al. 2008, Madi et al. 2014); positively and significantly influence the voluntary disclosure of corporate governance (Talpur et al. 2018); does not affect risk disclosure (Elzahar and Hussainey 2012). The next hypothesis in this paper is as follows:

H2: The size of the audit committee is positively associated with corporate risk disclosure.

\subsection{The frequency of audit committee meetings and corporate risk disclosure}

Audit committee activity is reflected in the number of audit committee meetings during one financial year (Talpur et al. 2018). The holding of the meeting can help the committee exchanged information, including the risk of the company to allow the identification and minimizes the risk of doing. The results showed that the frequency of audit committee meetings has a significant positive effect on the corporate disclosure level (Li et al. 2008, Li et al. 2012, Allegrini and Greco 2013, Taliyang and Jusop 2011, Ettredge et al. 2011); positively and significantly influence the voluntary disclosure (Talpur et al. 2018). Previous findings (Al-Maghzom et al. 2016) also show that audit committee meetings more often motivate banks to disclose more risk information. Based on the description above, the next hypothesis in this paper is as follows:

H3: The frequency of audit committee meetings is positively associated with corporate risk disclosure.

\subsection{Risk monitoring/management committee and corporate risk disclosure}

The company that owns the committee of risk monitoring or management are likely to evaluate internal oversight more effectively. They will operate independently with audit committees and work more effectively in carrying out the responsibility of overseeing risk management (Buckby et al. 2015) including ensuring risk disclosures are more complete and useful for stakeholders. The risk committee is considered as a governance mechanism for managing company risk, embracing risk and communicating risks with various stakeholders effectively (Nahar et al. 2016). Results of Meizaroh and Lucyanda (2011) showed that the availability of the risk management committee associated with corporate risk disclosure; has a significant effect on risk management disclosures (Buckby et al. 2015). Based on these, the next hypothesis in this paper is as follows:
H4: The availability of risk monitoring/management committee is positively associated with corporate risk disclosure.

\subsection{The quality of external auditor and corporate risk disclosure}

For the sake of reputation, auditors tend to demand higher disclosure (Chalmers and Godfrey 2004). Companies that use the services of the Big Four will get higher pressure (Chen et al. 2009) and influence disclosure (Dunn and Mayhew 2004). The company's financial statements audited by reputable independent auditors can also increase the level of investor confidence (Elshandidy and Neri 2015). The results of the prior study showed evidence that the type of audit firm is positively significantly associated with risk disclosure (Lopes and Rodrigues 2007, Mokhtar and Mellett 2013, Oliveira et al. 2011, Abid and Shaiq 2015, Carmona et al. 2016, Elshandidy and Neri 2015); has no significant effect (Al-Mutawaa and Hewaidy 2010) on corporate disclosure. Neifar and Jarboui (2018) also found evidence that the type of external auditor had a significant effect on operational risk information that included disclosure of voluntary Islamic banks. Based on the description above, the next hypothesis in this paper is as follows:

H5: The quality of external auditor is positively associated with corporate risk disclosure.

\subsection{Status of business entity and corporate risk disclosure}

Khan et al. (2013) stated that companies whose shares consist of foreign ownership tend to disclose the information to the decision-making process. The research showed that foreign-based companies have voluntary disclosure quality in the annual report are higher than domestic companies (Gunawan and Susanto 2004). Foreign-based companies change the behavior of in running operation to keep the reputation (Fauzi 2008, Simerly in Machmud and Djakman 2008). Based on the description above, the next hypothesis in this paper is as follows:

H6: Status of the business entity is positively associated with corporate risk disclosure.

\subsection{Age of business entity and corporate risk disclosure}

Disclosure of company information varies from time to time (Talpur et al. 2018). Therefore the age of the company can also be a factor that influences company disclosures including risk information. The company had long-standing (Bukh et al. 2005) have a smaller risk than the younger ones. The new company (younger) trying to reduce skepticism and enhance investor confidence (Haniffa and Cooke 2002). Based on the description above, the next hypothesis in this paper is as follows: 
H7: Age of business entity is negatively associated with corporate risk disclosure.

\section{Methods of research}

\subsection{Population and method of sampling}

In this study data collected based on annual reports of nonfinancial sector companies listed on the Indonesia stock exchange at the end of 2014. There were 420 non-financial companies listed on the Indonesian Stock Exchange. The sampling method in this paper used the purposive sampling. Based on the criteria have defined, the number of samples used was 312 non-financial companies (100 manufacturing and 212 non-manufacturing). The sampling process in this paper follows Table 1 below.

Table 1. Sample selection (source: data processing)

\begin{tabular}{|c|l|c|}
\hline No & \multicolumn{1}{|c|}{ Description } & Total \\
\hline 1 & $\begin{array}{l}\text { Companies (non-financial sector) listed in } \\
\text { Indonesia Stock Exchange (2014) }\end{array}$ & 420 \\
\hline 2 & $\begin{array}{l}\text { The company does not publish an annual } \\
\text { report for the 2014 period }\end{array}$ & $(8)$ \\
\hline 3 & $\begin{array}{l}\text { The company presents report does not end } \\
\text { on December 31 }\end{array}$ & $(5)$ \\
\hline 4 & Companies with incomplete data & $(95)$ \\
\hline Final Sample & 312 \\
\hline
\end{tabular}

\subsection{Measurement of variables}

Corporate risk disclosure in this paper is the dependent variable. The risk models used were based on the prior model developed by the Institute of Chartered Accountants in England and Wales (ICAEW) which also used the previous researchers (Mokhtar and Mellett 2013, Miihkinen 2013). Disclosure categorized in 6 (six) categories include financial risk; operational risk; empowerment risk; information processing and technology risk; integrity risk; and strategic risk with a total item 40 (see in Table 2). The measurement used scoring (Amran et al. 2009) with a score of 1 for the items disclosed and 0 if not revealed (not disclosed). The equation of risk disclosure index is as follows:

$C R D=\frac{\text { The number of risk disclosure that the company was done }}{\text { Total corporate risk disclosure items }}$.

Measurement of independent and control variables in this paper used measures such as in the following Table 3:

\subsection{Data analysis methods}

Data analysis used in this paper were a statistical analysis of multiple linear regression. Regression testing must be free from the classical assumptions (in this paper include normality of residual data, multicollinearity, and
Table 2. Risk disclosure items (source: Miihkinen 2013, Mokhtar and Mellett 2013)

\begin{tabular}{|l|l|}
\hline Financial risk & $\begin{array}{l}\text { Information processing and } \\
\text { technology risk }\end{array}$ \\
1. Commodity & 21. Integrity \\
3. Capital cost & 22. Access \\
& 23. Availability \\
Operational risk & 24. Infrastructure \\
4. Customer satisfaction & \\
5. Product development & Integrity risk \\
6. Efficiency and performance & 25. Management and emplo- \\
7. Sourcing & yee fraud \\
8. Stock obsolescence & 26. Illegal actions \\
9. Product and service failure & 27. Reputation \\
10. Environmental & 28. Risk management policy \\
11. Health and safety & 29. Risk management organi- \\
12. Brande name erosion & zation \\
13. Management process & \\
14. Price fluctuation of the & Strategic risk \\
factor of production & 30. Environmental scan \\
15. The interruption in the & 31. Industry \\
delivery chain & 32. Bussines portfolio \\
Empowerment risk & 33. Competitors \\
16. Leadership and manage- & 34. Pricing \\
ment & 35. Valuation \\
17. Outsourcing & 36. Planning \\
18. Performance incentives & 37. Lifecycle \\
19. Change readiness & 38. Performance measurement \\
20. Communications & 39. Regulatory \\
\hline
\end{tabular}

Table 3. Variables, acronyms, and measurement (source: authors' modification)

\begin{tabular}{|l|l|}
\hline \multicolumn{1}{|c|}{ Variables/Acronyms } & \multicolumn{1}{c|}{ Measurement } \\
\hline $\begin{array}{l}\text { Educational background of } \\
\text { president director (EDU) }\end{array}$ & $\begin{array}{l}1=\text { Business/finance and } \\
0=\text { Otherwise }\end{array}$ \\
\hline $\begin{array}{l}\text { Size of the audit committee } \\
\text { (SAC) }\end{array}$ & $\begin{array}{l}\text { Number of audit committee } \\
\text { member }\end{array}$ \\
\hline $\begin{array}{l}\text { The frequency of audit com- } \\
\text { mittee meetings (MAC) }\end{array}$ & $\begin{array}{l}\text { Number of audit committee } \\
\text { meetings }\end{array}$ \\
\hline $\begin{array}{l}\text { Risk monitoring/management } \\
\text { committee (RMC) }\end{array}$ & $\begin{array}{l}1=\text { There is a committee and } \\
0=\text { No }\end{array}$ \\
\hline $\begin{array}{l}\text { The quality of external auditor } \\
\text { (AUD) }\end{array}$ & $\begin{array}{l}1=\text { Big Four and } \\
0=\text { Otherwise }\end{array}$ \\
\hline $\begin{array}{l}\text { Status of the business entity } \\
\text { (STS) }\end{array}$ & $\begin{array}{l}1=\text { Foreign ownership and } \\
0=\text { Otherwise }\end{array}$ \\
\hline $\begin{array}{l}\text { Age of the business entity } \\
\text { (AGE) }\end{array}$ & $\begin{array}{l}\text { LN listing age of the business } \\
\text { entity }\end{array}$ \\
\hline Leverage (LEV) & Debt to asset ratio \\
\hline
\end{tabular}

heteroscedasticity). The model of regression in this study is as follows:

$$
\begin{aligned}
& C R D=\beta_{0}+\beta_{1} E D U+\beta_{2} S A C+\beta_{3} M A C+ \\
& \beta_{4} R M C+\beta_{5} A U D+\beta_{6} S T S+\beta_{7} A G E+\beta_{8} L E V+\varepsilon,
\end{aligned}
$$

where $C R D$ is the index of corporate risk disclosure; $E D U$ is educational background/expertise of director; $S A C$ is the 
size of the audit committee; $M A C$ is the frequency of audit committee meetings in one year; $R M C$ is the availability of a monitoring/risk management committee; $A U D$ is the quality of external auditor; STS is status of the business entity; $A G E$ is business entity age; and $L E V$ is leverage.

\section{Result and discussion}

\subsection{Descriptive analysis}

Descriptive statistics in this paper describes data that have been obtained which is useful to provide information from a group of data. In general, the statistical data of this research variables are shown in the following table summary:

Table 4. Descriptive statistics of risk disclosure (source: authors' calculation)

\begin{tabular}{|c|c|c|c|c|c|c|}
\hline Variable & $\mathrm{N}$ & Min & Mean & Median & Max & Std. Deviation \\
\hline CRD & 312 & 0.03 & 0.22 & 0.20 & 0.90 & 0.12 \\
\hline
\end{tabular}

Note: all companies.

Based on Table 4 above, the descriptive statistics show that the non-financial companies which consist of 312 companies on average do risk disclosure of 0.22 or $22 \%$. This indicates that Indonesia non-financial companies still have a shallow awareness of disclosing risks. This is probably due to the nature of the disclosure which is always voluntary (not required/mandatory).

Table 5. Descriptive statistics of independent variables (source: authors' calculation)

\begin{tabular}{|c|c|c|c|c|c|c|}
\hline $\begin{array}{c}\text { Va- } \\
\text { riables }\end{array}$ & N & Min & Mean & Median & Max & $\begin{array}{c}\text { Std. } \\
\text { Deviation }\end{array}$ \\
\hline SAC & 312 & 2.00 & 3.11 & 3.00 & 6.00 & 0.47 \\
\hline MAC & 312 & 1.00 & 7.13 & 5.00 & 59.00 & 7.08 \\
\hline AGE & 312 & 1.00 & 13.71 & 13.50 & 35.00 & 8.98 \\
\hline LEV & 312 & 0.02 & 0.54 & 0.49 & 7.69 & 0.54 \\
\hline
\end{tabular}

Notes: SAC is the size of the audit committee as measured by indicators of a large number of audit committee within the company; MAC is the frequency of audit committee meetings as measured by the frequency number of meetings in a year; AGE is business entity age as measured by indicators of the natural logarithm based on the listing in Indonesia Stock Exchange on the date the company listed on the Stock Exchange, December 31, 2014 (in years); and $\mathrm{LEV}$ is the level of leverage as measured using debt to asset ratio.

Based on the descriptive statistics Table 5 above, the average of the audit committee size is three persons, the average frequency of audit committee meetings is seven times, the standard age of business entity is 14 years, and the average of leverage is $54 \%$.

Table 6 shows that president of directors with educational background or expertise in business/finance of $68,91 \%$ and educational background or qualification on non-business
Table 6. Statistics of nominal independent variables (source: authors' calculation)

\begin{tabular}{|l|l|}
\hline \multicolumn{1}{|c|}{ Variables } & $\begin{array}{c}\text { Percentage } \\
\text { of Sample }\end{array}$ \\
\hline $\begin{array}{l}\text { Educational background/expertise of president } \\
\text { director (EDU): }\end{array}$ & \\
$\begin{array}{l}\text { 1. Business or financial } \\
\text { 2. Otherwise }\end{array}$ & 68.91 \\
\hline Risk monitoring/management committee & 31.09 \\
(RMC): & \\
1. There are Committee & 15.06 \\
2. No Committee & 84.94 \\
\hline External Auditor Quality (AUD): & \\
1. Big Four & 41.03 \\
2. Otherwise & 58.97 \\
\hline Firm status (STS): & 18.91 \\
1. Foreign ownership & 81.09 \\
2. Otherwise & $\mathrm{d}$ \\
\hline
\end{tabular}

Notes: EDU is educational background measured by dummy 1 if the president director has an educational background/expertise in business or finance and 0 for otherwise; RMC is the existence of a risk monitoring committee as measured with dummy 1 if there is a risk monitoring committee within the company and 0 otherwise; AUD is the quality of external auditors as measured by dummy 1 if the company in this study audited by the accounting firm that affiliated with an international accounting firm (Big Four) and 0 if otherwise; and STS is the status of a business entity as measured by dummy 1 if the company belonging to foreign ownership and 0 if otherwise

of $31,09 \%$. This table also shows that companies that have a risk monitoring/management committee of $15,06 \%$ and who do not have a risk monitoring/management committee of $84,94 \%$. The composition of the company with the kind of big four auditors of $41,03 \%$ and type of auditor other than the big four of $58,97 \%$. The base of companies with foreign ownership of $18,91 \%$ and the other $81,09 \%$.

\subsection{Hypotheses testing}

Hypothesis testing studies conducted to test the hypotheses of the research that has been put forward before. Testing was carried out by multiple regression analysis. The results of hypothesis testing in this study summarized in the following table:

Table 7 above shows that the adjusted value of $\mathrm{R}^{2}$ is $20.50 \%$. This value indicates that as much as $20.50 \%$ of the dependent variable in this study is corporate risk disclosure can be explained by the independent variables and the rest of the $79.50 \%(100 \%-20.50 \%)$ explained by other factors outside this research model. This table also shows that significant variables related to corporate risk disclosure are the size of the audit committee, the availability of risk monitoring committees, the quality of an external auditor, and the age of a business entity. 
Table 7. Results of testing hypotheses (source: authors' calculation)

\begin{tabular}{|c|c|c|c|c|}
\hline \multirow[b]{2}{*}{ Variables } & \multirow{2}{*}{$\begin{array}{l}\text { Predic- } \\
\text { tion }\end{array}$} & \multicolumn{2}{|c|}{ Model (CRD) } & \multirow[b]{2}{*}{ Conclusion } \\
\hline & & $\begin{array}{l}\text { Coeffi- } \\
\text { cient }\end{array}$ & $\begin{array}{l}\text { Signi- } \\
\text { ficance }\end{array}$ & \\
\hline Constants & & 0.137 & $0.002^{* *}$ & \\
\hline EDU & + & 0.000 & $0.981^{* *}$ & Not supported \\
\hline SAC & + & 0.031 & $0.025^{* *}$ & Supported \\
\hline MAC & + & 0.001 & $0.515^{* *}$ & Not supported \\
\hline RMC & + & 0.100 & $0.000^{* *}$ & Supported \\
\hline AUD & + & 0.033 & $0.011^{* *}$ & Supported \\
\hline STS & + & -0.025 & $0.107^{* *}$ & Not supported \\
\hline AGE & - & -0.020 & $0.002^{* *}$ & Supported \\
\hline LEV & \pm & 0.012 & $0.272^{* *}$ & \\
\hline \multicolumn{5}{|c|}{$\begin{array}{ll}R^{2}=0.225 & \text { Adjusted } R^{2}=0.205 \\
F \text { Value }=10.998 & \text { F Significant }=0.000\end{array}$} \\
\hline
\end{tabular}

** Significant at the level of 0.01 and ${ }^{\star}$ Significant at the level of 0.05 Notes: CRD is corporate risk disclosure; EDU is educational background measured by dummy 1 if the president director has an educational background/qualification in business or finance and 0 for otherwise; SAC is audit committee size as measured by indicators of a large number of audit committee within the company; MAC is the frequency of audit committee meetings as measured by the number of frequency of audit committee meetings in a year; RMC is the availability of a risk monitoring committee as measured with dummy 1 if there is a risk monitoring committee within the company and 0 otherwise; AUD is the quality of an external auditor as measured by dummy 1 if the companies audited by the accounting firm that affiliated with an international accounting firm (Big Four) and 0 if otherwise; STS is the status of a business entity as measured by dummy 1 if the companies belonging to foreign ownership and 0 if otherwise; AGE is age of a business entity as measured by indicators of the natural logarithm based on the listing in Indonesia Stock Exchange on the date, the company listed in Indonesia Stock Exchange, December 31, 2014 (in years); and LEV is the level of leverage as measured by debt to asset ratio.

\subsection{Discussion}

\subsubsection{The educational background/qualification of presi- dent director and corporate risk disclosure}

Educational background/qualification of president director (EDU) is not associated with corporate risk disclosure (H1 is not supported). The result of this research supports previous research (Haniffa and Cooke 2002) that found that educational background does not affect the disclosure. This Effect indicates that the educational background is not the only variable (primary factor) which will influence the decision in doing risk disclosure. The opposite effect of this research with the proposed hypothesis possibly because education is not only obtained through a formal channel. The educational background in this study is explicitly limited in the field of economics and business only, but there is the possibility of education company directors following business categories that can support the going concern of the company. Additionally, the capacity of this board of supervisors can also be affected by other things like training and experience which could influence decisions in providing advice such as corporate risk disclosure.

\subsubsection{The size of the audit committee and corporate risk disclosure}

The size of the audit committee (SAC) is significantly positively associated with corporate risk disclosure ( $\mathrm{H} 2$ supported). The result of this paper is consistent with the previous findings ( $\mathrm{Li}$ et al. 2008, Li et al. 2012, Madi et al. 2014) showed that the audit committee size has a significant positive effect on risk disclosure. This finding indicates the magnitude of the audit committee of the company owned by creating opportunities for the committee members to share or exchange information. So that it can reduce the action of beneficial management, including risk disclosure.

\subsubsection{The frequency of committee audit meetings and corporate risk disclosure}

The frequency of audit committee meetings (MAC) is not significantly associated with corporate risk disclosure (H3 not supported). The finding of this paper supports the statement (Menon and Williams 1994) that the frequency of meetings of the audit committee is not an indicator of carrying out tasks effectively and in contrast to previous studies (Li et al. 2008, Li et al. 2012, Allegrini and Greco 2013, Taliyang and Jusop 2011, Al-Maghzom et al. 2016, Talpur et al. 2018).

\subsubsection{Risk monitoring/management committee and corpo- rate risk disclosure}

Risk monitoring/ management committee (RMC) is significantly positively associated with corporate risk disclosure (H4 supported). This result is consistent with previous findings (Meizaroh and Lucyanda 2011, Buckby et al. 2015) who discovered the availability of the risk management committee has a significant positive effect on corporate risk disclosure. These findings indicate that the availability of a risk monitoring/risk management committee within a company can be more effectively evaluate internal controls particularly concerning corporate risk. This effectiveness is because of members of the risk monitoring committee assess and follow up on the possibility of a risk occurring. The existence of a risk monitoring committee assists the commissioner in carrying out the risk management supervision function and assessing risks, thereby enhancing the quality of risk assessment and encouraging the company on risk disclosure. 


\subsubsection{The quality of external auditors and corporate risk disclosure}

The external auditor quality (AUD) is significantly positively associated with corporate risk disclosure (H5 supported). The result of this paper is consistent with previous research (Lopes and Rodrigues 2007, Oliveira et al. 2011, Mokhtar and Mellett 2013, Abid and Shaiq 2015, Carmona et al. 2016, Elshandidy and Neri 2015). This indicates that external auditors audit the company with an international affiliate (Big Four) tend to do broader risk disclosure as it gets pressure from auditors as forms in maintaining a reputation. This finding also indicates that the auditor is the key to the external oversight mechanism of the organization and becomes the center of attention, especially for risk management. Auditor plays a role in improving effectiveness and creates good corporate governance.

\subsubsection{Status of business entity and corporate risk disclosure}

Ownership status (STS) is not significantly associated with corporate risk disclosure (H6 not supported). This research is inconsistent with previous findings (Gunawan and Susanto 2004) which found that foreign-based companies have higher exposure compared to domestic companies. This research supported previous findings (Said et al. 2018). This means that the status of foreign ownership of the company is not associated with corporate risk disclosure. This is likely to happen because the company is worried about losing investors if it discloses the risks because it is essential for foreign investors to conduct a long-term assessment of the company's prospects.

\subsubsection{Age of business entity and corporate risk disclosure}

The Variable of business entity age (AGE) is negatively associated with corporate risk disclosure (H7 supported). The result of this paper is consistent with all the previous statement (Bukh et al. 2005, Haniffa and Cooke 2002) but is not compatible with the results of previous studies (AlShammari et al. 2008, White et al. 2007). This is likely due to the regulation that is issued or the tendency of companies to entice the interest of potential investors.

Leverage variable indicates there is no significantly associated with corporate risk disclosure. This result conflicts with previous research (Hassan 2009) which found that the debt to the asset has a significant effect on risk disclosure.

\subsection{Sensitivity analysis}

This research was tested back separately into two categories based on the type of industry (manufacturing and nonmanufacturing). The results of the sensitivity testing are shown in the following table summary:
Table 8. Sensitivity analysis (source: authors' calculation)

\begin{tabular}{|c|c|c|c|c|c|}
\hline \multirow{3}{*}{ Variable } & \multirow{3}{*}{$\begin{array}{l}\text { Pred- } \\
\text { iction }\end{array}$} & \multicolumn{2}{|c|}{ Manufacturing } & \multicolumn{2}{|c|}{ Non-manufacturing } \\
\hline & & \multicolumn{2}{|c|}{ CRD } & \multicolumn{2}{|c|}{ CRD } \\
\hline & & Coef & Sig & Coef & Sig \\
\hline Constants & & 0.285 & $0.000^{* *}$ & 0.067 & $0.248^{\star *}$ \\
\hline EDU & + & -0.017 & $0.354^{\star *}$ & 0.004 & $0.835^{\star \star}$ \\
\hline SAC & + & 0.001 & $0.975^{* *}$ & 0.047 & $0.013^{\star *}$ \\
\hline MAC & + & -0.000 & $0.971^{* *}$ & 0.001 & $0.642^{\star *}$ \\
\hline RMC & + & 0.119 & $0.000^{* *}$ & 0.086 & $0.000^{\star *}$ \\
\hline AUD & + & 0.017 & $0.326^{* *}$ & 0.048 & $0.005^{\star \star}$ \\
\hline STS & + & -0.016 & $0.371^{\star *}$ & -0.011 & $0.633^{\star *}$ \\
\hline AGE & - & -0.034 & $0.000^{* *}$ & -0.012 & $0.181^{\star *}$ \\
\hline LEV & \pm & 0.001 & $0.972^{* *}$ & 0.015 & $0.251^{\star *}$ \\
\hline \multicolumn{2}{|l|}{$\mathrm{R}^{2}$} & \multicolumn{2}{|c|}{0.286} & \multicolumn{2}{|c|}{0.223} \\
\hline \multicolumn{2}{|l|}{ Adjusted $R^{2}$} & \multicolumn{2}{|c|}{0.223} & \multicolumn{2}{|c|}{0.192} \\
\hline \multicolumn{2}{|l|}{ F Value } & \multicolumn{2}{|c|}{4.546} & \multicolumn{2}{|c|}{7.283} \\
\hline \multicolumn{2}{|l|}{ F Significant } & \multicolumn{2}{|c|}{0.000} & \multicolumn{2}{|c|}{0.000} \\
\hline \multicolumn{2}{|l|}{$N$} & \multicolumn{2}{|c|}{100} & \multicolumn{2}{|c|}{212} \\
\hline
\end{tabular}

** Significant at the level of 0.01 and * Significant at the level of 0.05 Notes: CRD is corporate risk disclosure; EDU is educational background measured by dummy 1 if the president director has an educational background/qualification in business or finance and 0 for otherwise; SAC is audit committee size as measured by indicators of a large number of audit committee within the company; MAC is the frequency of audit committee meetings as measured by the number of frequency of audit committee meetings in a year; RMC is the availability of a risk monitoring committee as measured with dummy 1 if there is a risk monitoring committee within the company and 0 otherwise; AUD is the quality of an external auditor as measured by dummy 1 if the companies audited by the accounting firm that affiliated with an international accounting firm (Big Four) and 0 if otherwise; STS is the status of a business entity as measured by dummy 1 if the companies belonging to foreign ownership and 0 if otherwise; AGE is age of a business entity as measured by indicators of the natural logarithm based on the listing in Indonesia Stock Exchange on the date, the company listed in Indonesia Stock Exchange, December 31, 2014 (in years); and LEV is the level of leverage as measured by debt to asset ratio.

Sensitivity analysis based on Table 8 above, the variables that have a significant association on risk disclosure for the manufacturing company category are variable risk monitoring committee (RMC) and age (AGE). Variables that have a substantial effect on risk disclosure of these types of nonmanufacturing companies are the variable of the size of the audit committee (SAC), the availability of a risk monitoring committee (RMC), and the quality of external auditor (AUD). Table 8 shows that the adjusted $\mathrm{R}^{2}$ value of $22.30 \%$ of manufacturing companies and $19.20 \%$ of the non-manufacturing companies. These values indicate that the independent variables included in this study had a more significant influence on corporate risk disclosure in the manufacturing sector than the non-manufacturing sector. 


\section{Conclusions and suggestions}

This paper investigates the association between firm characteristics, corporate governance, and practices of corporate risk disclosure on non-financial companies. The nonfinancial companies which consist of 312 companies on average do risk disclosure of $22 \%$. This shows that Indonesia non-financial companies have still low awareness of disclosing the risks. The test results indicate that the educational background/qualification of president directors, the frequency of audit committee meetings, a status of the business entity and leverage are not significantly associated with corporate risk disclosure practices. Size of the audit committee, the availability of a risk monitoring, and quality of external auditor are significantly positively related to the practice of corporate risk disclosure while the age of business entity is significantly negatively associated with corporate risk disclosure practices. The variables of corporate governance and characteristics of business entities in this paper are only able to explain of $20.50 \%$ variable of corporate risk disclosure. These empirical results show that committee of risk monitoring or risk management, the quality of external auditor, and the size of the audit committee are primary factors of risk disclosure practices in non-financial companies listed on the Indonesia Stock Exchange.

This paper has several limitations that cannot be avoided by the researcher and can affect the research results. The period of observation in this study only one year, so it does not allow for generalized with the other research. Further research should use a more extended observation period, such as three or five (year) observations to find out the relationship or special events influences corporate risk disclosure. Decision making on risk disclosure practices is determined by the interpretations of researchers, to allow the occurrence of differences in assessment due to researchers. Decision making on risk disclosure should be discussed with the experts so as not to misinterpret and carry out simulations before collecting data for better reliability.

The variables used in this paper are limited only on educational background/qualification of the president director, the size of the audit committee, the frequency of audit committee meetings, the availability of risk monitoring or management committee, quality of external auditors, a status of the business entity, and age of business entity. Further research can add variables or other factors that may affect to corporate risk disclosure such as the gender diversity council or board of directors; government ownership; and the committee on corporate social responsibility or sustainability of efforts to further strengthen the research model to predict risk disclosure.

This paper investigates the association between business entity characteristics, corporate governance, and corporate risk disclosure practices where risk disclosure in this research is seen in general not specific. Further research should investigate the relationships between business entity characteristics, corporate governance, and corporate risk disclosure based on categories or dimensions. The results of this paper cannot be generalized and compared with other countries because the research results using purposive sampling to ensure the existence of the corporate risk disclosure. Further research may use different methods to provide the presence of the risk disclosure of companies such as random sampling. The study only focused on the company's annual report. Further research can do, not just focus on the development of the annual report but also through other statements that may provide information such as the company's interim reports or the company's website.

\section{Acknowledgements}

This paper is part of my masters' thesis conducted at Universitas Gadjah Mada. I thank my thesis advisor, Fuad Rakhman, for his guidance during completion of the thesis.

I also thank all members of the central research and community service institutions at the "Sekolah Tinggi Ilmu Ekonomi Muhammadiyah Palopo" for their support.

\section{References}

Abdullah M, Shukor ZA, Mohamed ZM, Ahmad A (2015) Risk management disclosure a study on the effect voluntary risk management disclosure toward firm value. Journal of Applied Accounting Research 16 (3): 400-432. https://doi.org/10.1018/ JAAR-10-2014-0106

Abid A, Shaiq M (2015) A study of risk disclosures in the annual reports of Pakistani companies: A content analysis. Research Journal of Finance and Accounting 6 (11): 14-24.

Abraham S, Cox P (2007) Analysing the determinants of narrative risk information in UK FTSE 100 annual reports. The British Accounting Review 39 (3): 227-248. https://doi.org/10.1016/j. bar.2007.06.002

Allegrini M, Greco G (2013) Corporate boards, audit committees, and voluntary disclosure: Evidence from Italian listed companies. Journal of Management and Governance 17 (1): 187-216. https://doi.org/10.1007/s10997-011-9168-3

Al-Maghzom A, Hussainey K, Aly D (2016) Corporate governance and risk disclosure: Evidence from Saudi Arabia. Corporate Ownership and Control 13 (2) https://ssrn.com/ abstract $=2720337$

Al-Mutawaa A, Hewaidy AM (2010) Disclosure level and compliance with IFRSs: An empirical investigation of Kuwaiti companies. International Business and Economics Research Journal (IBER) 9 (5): 33-50. https://doi.org/10.19030/iber. v9i5.566

Al-Shammari B, Brown P, Tarca A (2008) An investigation of compliance with international accounting standards by listed companies in the Gulf co-operation council member states. The International Journal of Accounting 43 (4): 425-447. https://doi.org/10.1016/j.intacc.2008.09.003 
Amran A, Bin AMR, Hassan BCHM (2009) Risk reporting an exploratory study on risk management disclosure in Malaysian annual reports. Managerial Auditing Journal 24 (1): 39-57. https://doi.org/10.1108/02686900910919893

Ararat M, Mine A, Cetin AT (2010) The impact of board diversity on boards' monitoring intensity and firm performance: Evidence from the Istanbul Stock Exchange. SSRN Electronic Journal 90 (216): 1-33. https://doi.org/10.2139/ssrn.1572283

Bamber, Smith L, Jiang J, Wang IY (2010) What's my style? The influence of top managers on voluntary corporate financial disclosure. The Accounting Review 85 (4): 1131-1162. https:// doi.org/10.2308/accr.2010.85.4.1131

Bank Indonesia Regulation Number 8 of 2006 Implementation of good corporate governance for commercial banks. October 5, 2006. The Sheet of the Republik Indonesia in 2006 Number 71. Jakarta.

Bank Indonesia Regulation Number 14 of 2012 Concerning transparency and publication of bank reports. October 18, 2012. The Sheet of the Republik Indonesia in 2012 Number 199. Jakarta.

Buckby S, Gallery G, Ma J (2015) An analysis of risk management disclosures: Australian evidence. Managerial Auditing Journal 30 (8/9): 812-869. https://doi.org/10.1108/MAJ-09-2013-0934

Bukh PN, Nielsen C, Gormsen P, Mouritsen J (2005) Disclosure of information on intellectual capital in Danish IPO prospectuses. Accounting, Auditing, and Accountability Journal 18 (6): 713-732. https://doi.org/10.1108/09513570510627685

Carmona P, Fuentes CD, Ruiz C (2016) Risk disclosure analysis in the corporate governance annual report using fuzzy-set qualitative comparative analysis. Revista de Administração de Empresas 56 (3): 342-352. https://doi.org/10.1590/S0034759020160307

Chakraborty A, Gao L, Sheikh S (2018) Corporate governance and risk in cross-listed and Canadian only companies. Management Decision. https://doi.org/10.1108/MD-10-2017-1052

Chalmers K, Godfrey J (2004) Reputation costs: The Impetus for voluntary derivative financial instrument reporting. Accounting, Organizations and Society 29 (2): 95-125. https://doi. org/10.1016/S0361-3682(02)00034-X

Chen LG, Kilgore A, Radich R (2009) Audit committees: Voluntary formation by ASX non-top 500. Managerial Auditing Journal 24 (5): 475-493. https://doi.org/10.1108/02686900910956829

Choi FDS, Meek GK (2011) International accounting (7th ed). New Jersey: Prentice Hall.

Cotter J, Silvester M (2008) Board and monitoring committee independence. A Journal of Accounting, Finance, and Business Studies 39 (2): 211-232. https://doi.org/10.1111/14676281.00127

Dimaggio PJ, Powell WW (1983) The iron cage revisited: Institutional isomorphism and collective rationality in organizational fields. American Sociological Review 48 (2): 147-160. https://doi.org/10.2307/2095101

Dobler M (2008) Incentives for risk reporting-A discretionary disclosure and cheap talk approach. The International Journal of Accounting 43 (2): 184-206. https://doi.org/10.1016/j. intacc.2008.04.005

Dunn KA, Mayhew BW (2004) Audit firm industry specialization and client disclosure quality. Review of Accounting Studies
9 (1): 35-58. https://doi.org/10.1023/B:RAST.0000013628. 49401.69

Elshandidy T, Neri R (2015) Corporate governance, risk disclosure practices, and market liquidity: comparative evidence from the UK and Italy. Corporate Governance: An International Review 23 (4): 331-356. https://doi.org/10.1111/corg.12095

Elzahar H, Hussainey K (2012) Determinants of narrative risk disclosures in UK interim reports. The Journal of Risk Finance 13 (2): 133-147. https://doi.org/10.1108/15265941211203189

Ettredge M, Johnstone K, Stone M, Wang Q (2011) The effects of firm size, corporate governance quality, and bad news on disclosure compliance. Review of Accounting Studies 16 (4): 866-889. https://doi.org/10.1007/s11142-011-9153-8

Fauzi H (2008) Corporate social and environmental performance: A comparative study of Indonesian companies and multinational companies (MNCs) operating in Indonesia. Journal of Knowledge Globalization 1 (1): 81-105.

FCGI (2000) The roles of the board of commissioners and the audit committee www.fcgi.or.id

Gunawan I, Susanto (2004) The influence of ownership structure on the extent of CSR disclosure in the company's annual report: An empirical study on public companies listed on the Indonesia Stock Exchange in 2006. National Accounting Symposium 15 (1): 75-86.

Haniffa RM, Cooke TE (2002) Culture, corporate governance, and disclosure in Malaysian corporations. Abacus 38 (3): 317-349. https://doi.org/10.1111/1467-6281.00112

Hassan MK (2009) UAE corporations - specific characteristics and level of risk disclosure. Managerial Auditing Journal 24 (7): 668-687. https://doi.org/10.1108/02686900910975378

Ho SSM, Wong KS (2001) A study of the relationship between corporate governance structures and the extent of voluntary disclosure. Journal of International Accounting, Auditing, and Taxation 10 (2): 139-156. https://doi.org/10.1016/S10619518(01)00041-6

IFRS, P (2010) IFRS practice statement management commentary. A framework for presentation. London: IFRS Foundation.

Jensen MC, Meckling WH (1976) Theory of the firm: managerial behavior, agency costs, and ownership structure. Journal of Financial Economics 3 (4): 305-360. https://doi. org/10.1016/0304-405X(76)90026-X

Khan A, Muttakin MB, Siddiqui J (2013) Corporate governance and corporate social responsibility disclosures: Evidence from an emerging economy. Journal of Business Ethics 114 (2): 207-223. https://doi.org/10.1007/s10551-012-1336-0

Krishnamurti C, Velayutham E (2018) The influence of board committee structures on voluntary disclosure of greenhouse gas emissions: Australian evidence. Pasific-Basin Finance Journal 50: 65-81. https://doi.org/10.1016/j.pacfin.2017. 09.003

Li J, Mangena M, Pike R (2012) The effect of audit committee characteristics on intellectual capital disclosure. The British Accounting Review 44 (2): 98-110. https://doi.org/10.1016/j. bar.2012.03.003

Li J, Pike R, Haniffa R (2008) Intellectual capital disclosure and corporate governance structure in UK firms. Accounting and Business Research 38 (2): 136-159. https://doi.org/10.1080/0 0014788.2008 .9663326 
Linsley PM, Shrives PJ (2006) Risk reporting: A study of risk disclosures in the annual reports of UK companies. British Accounting Review 38 (4): 387-404. https://doi.org/10.1016/j. bar.2006.05.002

Lopes PT, Rodrigues LL (2007) Accounting for financial instruments: An analysis of the determinants of disclosure in the Portuguese Stock Exchange. The International Journal of Accounting 42 (1): 25-56. https://doi.org/10.1016/j.intacc.2006.12.002

Machmud N, Djakman CD (2008) Effect of ownership structure on the extent of CSR disclosure in the company's annual report: An empirical study of public companies listed on the Indonesia Stock Exchange in 2006. In Accounting National Symposium. Pontianak.

Madi HK, Ishak Z, Manaf NAB (2014) The impact of audit committee characteristics on corporate voluntary disclosure. Procedia-Social and Behavioral Sciences 164 (August): 486492. https://doi.org/10.1016/j.sbspro.2014.11.106

Madrigal MH, Guzman BA, Guzman CA (2015) Determinants of corporate risk disclosure in large Spanish companies: A snapshot. Contaduria y Administracion 60 (4): 757-775. https://doi.org/10.1016/j.cya.2015.05.014

Meizaroh, Lucyanda J (2011) The influence of corporate governance and concentration of ownership on enterprise risk management disclosure. National Accounting Symposium IV Aceh, July 21-22, 1-30 pp.

Menon K, Williams JD (1994) The use of audit committees for monitoring. Journal of Accounting and Public Policy 13 (2): 121-139. https://doi.org/10.1016/0278-4254(94)90016-7

Miihkinen A (2013) The usefulness of firm risk disclosures under different firm riskiness, investor-interest, and market conditions: new evidence from Finland. Advances in Accounting 29 (2): 312-331. https://doi.org/10.1016/j.adiac.2013.09.006

Mokhtar ES, Mellett H (2013) Competition, corporate governance, ownership structure, and risk reporting. Managerial Auditing Journal 28 (9): 838-865. https://doi.org/10.1108/ MAJ-11-2012-0776

Monks RAG, Minow N (2011) Corporate governance (5th ed). United States: John Willey.

Morris RD (1987) Signaling, agency theory, and accounting policy choice. Accounting and Business Research 18 (69): 47-56. https://doi.org/10.1080/00014788.1987.9729347

Nahar S, Jubb C, Azim MI (2016) Risk governance and performance: a developing country perspective. Managerial Auditing Journal 31 (3): 250-268. https://doi.org/10.1108/ MAJ-02-2015-1158

Neifar S, Jarboui A (2018) Corporate governance and operational risk voluntary disclosure: Evidence from islamic banks. Research in International Business and Finance 46: 43-54. https://doi.org/10.1016/j.ribaf.2017.09.006

Oliveira J, Rodrigues LL, and Craig R (2011) Risk-related disclosures by non-finance companies Portuguese practices and disclosure characteristics. Managerial Auditing Journal 26 (9): 817-839. https://doi.org/10.1108/02686901111171466
Owusu-Ansah S (1998) The impact of corporate attributes on the extent of mandatory disclosure and reporting by listed companies in Zimbabwe. The International Journal of Accounting 33 (5): 605-631. https://doi.org/10.1016/S0020-7063(98)90015-2

Owusu-Ansah S, Yeoh J (2005) The Effect of legislation on corporate disclosure practices. Abacus 41 (1): 92-109. https:// doi.org/10.1111/j.1467-6281.2005.00171.x

Probohudono AN, Tower G, Rusmin R (2013) Risk disclosure during the global financial crisis. Social Responsibility Journal 9 (1): 124-137. https://doi.org/10.1108/17471111311307859

Said R, Omar N, Abdullah WN (2013) Empirical investigations on boards, business characteristics, human capital and environmental reporting. Social Responsibility Journal 9 (4): 534-553. https://doi.org/10.1108/SRJ-02-2012-0019

Said R, Rahim AAA, Hassan R (2018) Exploring the effects of corporate governance and human governance on management commentary disclosure. Social Responsibility Journal 14 (4): 842-858. https://doi.org/10.1108/SRJ-06-2017-0099

Siregar SV, Bachtiar Y (2010) Corporate social reporting: Empirical evidence from Indonesia stock exchange. International Journal of Islamic and Middle Eastern Finance and Management 3 (3): 241-252. https://doi.org/10.1108/17538391011072435

Subramaniam N, McManus L, Zhang J (2009) Corporate governance, firm characteristics and risk management committee formation in Australian companies. Managerial Auditing Journal 24 (4): 316-339. https://doi.org/10.1108/ 02686900910948170

Suhardjanto D (2011) Disclosure of financial risk and corporate governance: An empirical study of Indonesian banking. Journal of Finance and Banking 15 (1): 105-118.

Taliyang SM, Jusop M (2011) Intellectual capital disclosure and corporate governance structure: Evidence in Malaysia. International Journal of Business and Management 6 (12): 109-117. https://doi.org/10.5539/ijbm.v6n12p109

Talpur S, Lizam M, Zabri SM (2018) Do audit committee structure increases influence the level of voluntary corporate governance disclosures. Property Management 36 (5): 544-561. https:// doi.org/10.1108/PM-07-2017-0042

Wallace RSO, Coocke TE (1990) The diagnosis and resolution of emerging issue in corporate disclosures practices. Accounting and Business Research 20 (78): 143-151. https://doi.org/10.1 080/00014788.1990.9728872

White G, Lee A, Tower G (2007) Drivers of voluntary intellectual capital disclosure in listed biotechnology companies. Journal of Intellectual Capital 8 (3): 517-537. https://doi. org/10.1108/14691930710774894

Williams KY, O’Reilly CA (1998) Demography and diversity in organizations: A review of 40 years of research. Research in Organizational Behavior 20: 77-140.

Zadeh FO, Rasid SZA, Basiruddin R, Zamil NAM, Vakilbashi A (2016) Risk disclosure practices among Malaysian listed firms. International Journal of Economics and Financial Issues 6 (3): 1092-1096. 


\section{APPENDIX}

Table A1. List of Sample (source: authors' sampling of Indonesian Stock Exchange)

\begin{tabular}{|c|c|c|c|c|c|}
\hline No & Code & Listed companies & No & Code & Listed companies \\
\hline 1 & ABMM & ABM Investama Tbk. & 39 & BISI & BISI International Tbk. \\
\hline 2 & ACST & Acset Indonusa Tbk. & 40 & BKDP & Bukit Darmo Property Tbk \\
\hline 3 & ADES & Akasha Wira International Tbk. & 41 & BKSL & Sentul City Tbk. \\
\hline 4 & ADHI & Adhi Karya (Persero) Tbk. & 42 & BLTA & Berlian Laju Tanker Tbk \\
\hline 5 & ADMG & Polychem Indonesia Tbk & 43 & BLTZ & Graha Layar Prima Tbk. \\
\hline 6 & ADRO & Adaro Energy Tbk. & 44 & BMSR & Bintang Mitra Semestaraya Tbk \\
\hline 7 & AISA & Tiga Pilar Sejahtera Food Tbk. & 45 & BMTR & Global Mediacom Tbk. \\
\hline 8 & AKPI & Argha Karya Prima Industry Tbk. & 46 & BNBR & Bakrie \& Brothers Tbk. \\
\hline 9 & AKRA & AKR Corporindo Tbk. & 47 & BRAM & Indo Kordsa Tbk. \\
\hline 10 & ALDO & Alkindo Naratama Tbk. & 48 & BRAU & Berau Coal Energy Tbk. \\
\hline 11 & ALKA & Alakasa Industrindo Tbk & 49 & BRMS & Bumi Resources Minerals Tbk. \\
\hline 12 & AMFG & Asahimas Flat Glass Tbk. & 50 & BRNA & Berlina Tbk. \\
\hline 13 & AMRT & Sumber Alfaria Trijaya Tbk. & 51 & BSDE & Bumi Serpong Damai Tbk. \\
\hline 14 & ANJT & Austindo Nusantara Jaya Tbk. & 52 & BTEK & Bumi Teknokultura Unggul Tbk \\
\hline 15 & ANTM & Aneka Tambang (Persero) Tbk. & 53 & BTEL & Bakrie Telecom Tbk. \\
\hline 16 & APEX & Apexindo Pratama Duta Tbk. & 54 & BTON & Betonjaya Manunggal Tbk. \\
\hline 17 & APII & Arita Prima Indonesia Tbk. & 55 & BUDI & Budi Starch \& Sweetener Tbk. \\
\hline 18 & APLN & Agung Podomoro Land Tbk. & 56 & BULL & Buana Listya Tama Tbk. \\
\hline 19 & APOL & Arpeni Pratama Ocean Line Tbk. & 57 & BUMI & Bumi Resources Tbk. \\
\hline 20 & ARII & Atlas Resources Tbk. & 58 & BWPT & Eagle High Plantations Tbk. \\
\hline 21 & ARNA & Arwana Citramulia Tbk. & 59 & BYAN & Bayan Resources Tbk. \\
\hline 22 & ARTI & Ratu Prabu Energi Tbk & 60 & CASS & Cardig Aero Services Tbk. \\
\hline 23 & ASGR & Astra Graphia Tbk. & 61 & CINT & Chitose Internasional Tbk. \\
\hline 24 & ASII & Astra International Tbk. & 62 & CKRA & Cakra Mineral Tbk. \\
\hline 25 & ASRI & Alam Sutera Realty Tbk. & 63 & CMNP & Citra Marga Nusaphala Persada Tbk. \\
\hline 26 & ASSA & Adi Sarana Armada Tbk. & 64 & CMPP & Rimau Multi Putra Pratama \\
\hline 27 & ATPK & Bara Jaya International Tbk. & 65 & COWL & Cowell Development Tbk. \\
\hline 28 & AUTO & Astra Otoparts Tbk. & 66 & CPGT & Citra Maharlika Nusantara Corpora Tbk. \\
\hline 29 & BAPA & Bekasi Asri Pemula Tbk. & 67 & CPIN & Charoen Pokphand Indonesia Tbk \\
\hline 30 & BATA & Sepatu Bata Tbk. & 68 & $\mathrm{CPRO}$ & Central Proteina Prima Tbk. \\
\hline 31 & BBRM & Pelayaran Nasional Bina Buana Raya & 69 & CSAP & Catur Sentosa Adiprana Tbk. \\
\hline 32 & BCIP & Bumi Citra Permai Tbk. & 70 & CTBN & Citra Tubindo Tbk. \\
\hline 33 & BEST & Bekasi Fajar Industrial Estate Tbk. & 71 & CTRA & Ciputra Development Tbk. \\
\hline 34 & BHIT & MNC Investama Tbk. & 72 & CTRP & Ciputra Property Tbk. \\
\hline 35 & BIMA & Primarindo Asia Infrastructure Tbk. & 73 & CTRS & Ciputra Surya Tbk. \\
\hline 36 & BIPI & Benakat Integra Tbk. & 74 & СTTH & Citatah Tbk. \\
\hline 37 & BIPP & Bhuwanatala Indah Permai Tbk. & 75 & DART & Duta Anggada Realty Tbk. \\
\hline 38 & BIRD & Blue Bird Tbk. & 76 & DEWA & Darma Henwa Tbk. \\
\hline 77 & DGIK & Nusa Konstruksi Enjiniring Tbk. & 116 & GMTD & Gowa Makassar Tourism Development Tbk. \\
\hline
\end{tabular}




\begin{tabular}{|c|c|c|c|c|c|}
\hline No & Code & Listed companies & No & Code & Listed companies \\
\hline 78 & DILD & Intiland Development Tbk. & 117 & GOLD & Golden Retailindo Tbk. \\
\hline 79 & DKFT & Central Omega Resources Tbk. & 118 & GPRA & Perdana Gapura Prima Tbk. \\
\hline 80 & DLTA & Delta Djakarta Tbk. & 119 & GREN & Evergreen Invesco Tbk. \\
\hline 81 & DOID & Delta Dunia Makmur Tbk. & 120 & GWSA & Greenwood Sejahtera Tbk. \\
\hline 82 & DPNS & Duta Pertiwi Nusantara Tbk. & 121 & HDTX & Panasia Indo Resources Tbk. \\
\hline 83 & DSFI & Dharma Samudera Fishing Industries & 122 & HERO & Hero Supermarket Tbk. \\
\hline 84 & DSNG & Dharma Satya Nusantara Tbk. & 123 & HMSP & H.M. Sampoerna Tbk. \\
\hline 85 & DSSA & Dian Swastatika Sentosa Tbk & 124 & HRUM & Harum Energy Tbk. \\
\hline 86 & DUTI & Duta Pertiwi Tbk & 125 & IATA & Indonesia Transport \& Infrastructure Tbk. \\
\hline 87 & DVLA & Darya-Varia Laboratoria Tbk. & 126 & IBST & Inti Bangun Sejahtera Tbk. \\
\hline 88 & DYAN & Dyandra Media International Tbk. & 127 & ICBP & Indofood CBP Sukses Makmur Tbk. \\
\hline 89 & EKAD & Ekadharma International Tbk. & 128 & ICON & Island Concepts Indonesia Tbk. \\
\hline 90 & ELSA & Elnusa Tbk. & 129 & IGAR & Champion Pacific Indonesia Tbk. \\
\hline 91 & ELTY & Bakrieland Development Tbk. & 130 & IIKP & Inti Kapuas Arowana Tbk. \\
\hline 92 & EMTK & Elang Mahkota Teknologi Tbk. & 131 & IMAS & Indomobil Sukses Internasional Tbk. \\
\hline 93 & ENRG & Energi Mega Persada Tbk. & 132 & INAF & Indofarma Tbk. \\
\hline 94 & EPMT & Enseval Putera Megatrading Tbk. & 133 & INCO & Vale Indonesia Tbk. \\
\hline 95 & ERAA & Erajaya Swasembada Tbk. & 134 & INDF & Indofood Sukses Makmur Tbk. \\
\hline 96 & ERTX & Eratex Djaja Tbk. & 135 & INDR & Indo-Rama Synthetics Tbk. \\
\hline 97 & ESSA & Surya Esa Perkasa Tbk. & 136 & INDS & Indospring Tbk. \\
\hline 98 & ETWA & Eterindo Wahanatama Tbk & 137 & INDX & Tanah Laut Tbk \\
\hline 99 & EXCL & XL Axiata Tbk. & 138 & INDY & Indika Energy Tbk. \\
\hline 100 & FASW & Fajar Surya Wisesa Tbk. & 139 & INKP & Indah Kiat Pulp \& Paper Tbk. \\
\hline 101 & FISH & FKS Multi Agro Tbk. & 140 & INPP & Indonesian Paradise Property Tbk. \\
\hline 102 & FMII & Fortune Mate Indonesia Tbk & 141 & INRU & Toba Pulp Lestari Tbk. \\
\hline 103 & FORU & Fortune Indonesia Tbk & 142 & INTA & Intraco Penta Tbk. \\
\hline 104 & FPNI & Lotte Chemical Titan Tbk. & 143 & INTD & Inter-Delta Tbk \\
\hline 105 & FREN & Smartfren Telecom Tbk. & 144 & INTP & Indocement Tunggal Prakasa Tbk. \\
\hline 106 & GAMA & Gading Development Tbk. & 145 & IPOL & Indopoly Swakarsa Industry Tbk. \\
\hline 107 & GDST & Gunawan Dianjaya Steel Tbk. & 146 & ISAT & Indosat Tbk. \\
\hline 108 & GDYR & Goodyear Indonesia Tbk. & 147 & ITMG & Indo Tambangraya Megah Tbk. \\
\hline 109 & GEMA & Gema Grahasarana Tbk. & 148 & ITTG & Leo Investments Tbk. \\
\hline 110 & GEMS & Golden Energy Mines Tbk. & 149 & JAWA & Jaya Agra Wattie Tbk. \\
\hline 111 & GGRM & Gudang Garam Tbk. & 150 & JECC & Jembo Cable Company Tbk. \\
\hline 112 & GIAA & Garuda Indonesia (Persero) Tbk. & 151 & JIHD & Jakarta International Hotels \& Development Tbk \\
\hline 113 & GJTL & Gajah Tunggal Tbk. & 152 & JKSW & Jakarta Kyoei Steel Works Tbk. \\
\hline 114 & GLOB & Global Teleshop Tbk. & 153 & JPFA & Japfa Comfeed Indonesia Tbk. \\
\hline 115 & GMCW & Grahamas Citrawisata Tbk. & 154 & JPRS & Jaya Pari Steel Tbk \\
\hline 155 & JSMR & Jasa Marga Tbk. & 194 & MIDI & Midi Utama Indonesia Tbk. \\
\hline 156 & JTPE & Jasuindo Tiga Perkasa Tbk. & 195 & MKPI & Metropolitan Kentjana Tbk. \\
\hline 157 & KBLI & KMI Wire \& Cable Tbk. & 196 & MLBI & Multi Bintang Indonesia Tbk. \\
\hline 158 & KBLM & Kabelindo Murni Tbk. & 197 & MLIA & Mulia Industrindo Tbk \\
\hline 159 & KBLV & First Media Tbk. & 198 & MLPL & Multipolar Tbk. \\
\hline 160 & KBRI & Kertas Basuki Rachmat Indonesia Tbk. & 199 & MLPT & Multipolar Technology Tbk. \\
\hline
\end{tabular}




\begin{tabular}{|c|c|c|c|c|c|}
\hline No & Code & Listed companies & No & Code & Listed companies \\
\hline 161 & KIAS & Keramika Indonesia Assosiasi Tbk. & 200 & MNCN & Media Nusantara Citra Tbk. \\
\hline 162 & KICI & Kedaung Indah Can Tbk & 201 & MPMX & Mitra Pinasthika Mustika Tbk. \\
\hline 163 & KIJA & Kawasan Industri Jababeka Tbk. & 202 & MPPA & Matahari Putra Prima Tbk. \\
\hline 164 & KKGI & Resource Alam Indonesia Tbk. & 203 & MRAT & Mustika Ratu Tbk. \\
\hline 165 & KLBF & Kalbe Farma Tbk. & 204 & MSKY & MNC Sky Vision Tbk. \\
\hline 166 & KOBX & Kobexindo Tractors Tbk. & 205 & MTDL & Metrodata Electronics Tbk. \\
\hline 167 & KOIN & Kokoh Inti Arebama Tbk & 206 & MTLA & Metropolitan Land Tbk. \\
\hline 168 & KPIG & MNC Land Tbk. & 207 & MYOH & Samindo Resources Tbk. \\
\hline 169 & KRAH & Grand Kartech Tbk. & 208 & MYOR & Mayora Indah Tbk. \\
\hline 170 & KRAS & Krakatau Steel (Persero) Tbk. & 209 & MYRX & Hanson International Tbk. \\
\hline 171 & LCGP & Eureka Prima Jakarta Tbk. & 210 & NELY & Pelayaran Nelly Dwi Putri Tbk. \\
\hline 172 & LEAD & Logindo Samudramakmur Tbk. & 211 & NIKL & Pelat Timah Nusantara Tbk. \\
\hline 173 & LION & Lion Metal Works Tbk. & 212 & NIRO & Nirvana Development Tbk. \\
\hline 174 & LMPI & Langgeng Makmur Industri Tbk. & 213 & NRCA & Nusa Raya Cipta Tbk. \\
\hline 175 & LMSH & Lionmesh Prima Tbk. & 214 & OKAS & Ancora Indonesia Resources Tbk. \\
\hline 176 & LPCK & Lippo Cikarang Tbk & 215 & PALM & Provident Agro Tbk. \\
\hline 177 & LPIN & Multi Prima Sejahtera Tbk & 216 & PBRX & Pan Brothers Tbk. \\
\hline 178 & LPKR & Lippo Karawaci Tbk. & 217 & PDES & Destinasi Tirta Nusantara Tbk \\
\hline 179 & LPLI & Star Pacific Tbk. & 218 & PGAS & Perusahaan Gas Negara (Persero) Tbk. \\
\hline 180 & LPPF & Matahari Department Store Tbk. & 219 & PGLI & Pembangunan Graha Lestari Indah Tbk. \\
\hline 181 & LRNA & Eka Sari Lorena Transport Tbk. & 220 & PJAA & Pembangunan Jaya Ancol Tbk. \\
\hline 182 & LSIP & PP London Sumatra Indonesia Tbk. & 221 & PKPK & Perdana Karya Perkasa Tbk \\
\hline 183 & MAIN & Malindo Feedmill Tbk. & 222 & PLAS & Polaris Investama Tbk \\
\hline 184 & MAMI & Mas Murni Indonesia Tbk & 223 & PLIN & Plaza Indonesia Realty Tbk. \\
\hline 185 & MBAP & Mitrabara Adiperdana Tbk. & 224 & PNSE & Pudjiadi \& Sons Tbk. \\
\hline 186 & MBSS & Mitrabahtera Segara Sejati Tbk. & 225 & POOL & Pool Advista Indonesia Tbk. \\
\hline 187 & MBTO & Martina Berto Tbk. & 226 & PRAS & Prima Alloy Steel Universal Tbk. \\
\hline 188 & MDLN & Modernland Realty Ltd Tbk & 227 & PSKT & Red Planet Indonesia Tbk. \\
\hline 189 & MDRN & Modern Internasional Tbk. & 228 & PTBA & Tambang Batubara Bukit Asam (Persero) \\
\hline 190 & MEDC & Medco Energi International Tbk. & 229 & PTPP & Indo Straits Tbk. \\
\hline 191 & META & Nusantara Infrastructure Tbk. & 230 & PTRO & PP (Persero) Tbk. \\
\hline 192 & MFMI & Multifiling Mitra Indonesia Tbk. & 231 & PTSP & Petrosea Tbk. \\
\hline 193 & MICE & Multi Indocitra Tbk. & 232 & PUDP & Pioneerindo Gourmet International Tbk. \\
\hline 233 & PWON & Pakuwon Jati Tbk. & 273 & SULI & SLJ Global Tbk. \\
\hline 234 & RAJA & Rukun Raharja Tbk. & 274 & TALF & Tunas Alfin Tbk. \\
\hline 235 & RALS & Ramayana Lestari Sentosa Tbk. & 275 & TAXI & Express Transindo Utama Tbk. \\
\hline 236 & RANC & Supra Boga Lestari Tbk. & 276 & TBIG & Tower Bersama Infrastructure Tbk. \\
\hline 237 & RBMS & Ristia Bintang Mahkotasejati Tbk. & 277 & TBMS & Tembaga Mulia Semanan Tbk. \\
\hline 238 & RICY & Ricky Putra Globalindo Tbk & 278 & TCID & Mandom Indonesia Tbk. \\
\hline 239 & RMBA & Bentoel Internasional Investama Tbk. & 279 & TELE & Tiphone Mobile Indonesia Tbk. \\
\hline 240 & RODA & Pikko Land Development Tbk. & 280 & TFCO & Tifico Fiber Indonesia Tbk. \\
\hline 241 & ROTI & Nippon Indosari Corpindo Tbk. & 281 & TGKA & Tigaraksa Satria Tbk. \\
\hline 242 & RUIS & Radiant Utama Interinsco Tbk. & 282 & TINS & Timah (Persero) Tbk. \\
\hline 243 & SAFE & Steady Safe Tbk & 283 & TIRA & Tira Austenite Tbk \\
\hline
\end{tabular}




\begin{tabular}{|c|c|c|c|c|c|}
\hline No & Code & Listed companies & No & Code & Listed companies \\
\hline 244 & SCMA & Surya Citra Media Tbk. & 284 & TKIM & Pabrik Kertas Tjiwi Kimia Tbk. \\
\hline 245 & SDMU & Sidomulyo Selaras Tbk. & 285 & TLKM & Telekomunikasi Indonesia (Persero) Tbk. \\
\hline 246 & SDPC & $\begin{array}{l}\text { Millennium Pharmacon International } \\
\text { Tbk. }\end{array}$ & 286 & TMAS & Pelayaran Tempuran Emas Tbk. \\
\hline 247 & SGRO & Sampoerna Agro Tbk. & 287 & TOBA & Toba Bara Sejahtra Tbk. \\
\hline 248 & SIAP & Sekawan Intipratama Tbk & 288 & TOTL & Total Bangun Persada Tbk. \\
\hline 249 & SILO & Siloam International Hospitals Tbk. & 289 & TOTO & Surya Toto Indonesia Tbk. \\
\hline 250 & SIMP & Salim Ivomas Pratama Tbk. & 290 & TOWR & Sarana Menara Nusantara Tbk. \\
\hline 251 & SIPD & Sierad Produce Tbk. & 291 & TPIA & Chandra Asri Petrochemical Tbk. \\
\hline 252 & SKBM & Sekar Bumi Tbk. & 292 & TPMA & Trans Power Marine Tbk. \\
\hline 253 & SKLT & Sekar Laut Tbk. & 293 & TRAM & Trada Maritime Tbk. \\
\hline 254 & SKYB & Skybee Tbk. & 294 & TRIO & Trikomsel Oke Tbk. \\
\hline 255 & SMAR & Smart Tbk. & 295 & TRIS & Trisula International Tbk. \\
\hline 256 & SMBR & Semen Baturaja (Persero) Tbk. & 296 & TRST & Trias Sentosa Tbk. \\
\hline 257 & SMCB & Holcim Indonesia Tbk. & 297 & TURI & Tunas Ridean Tbk. \\
\hline 258 & SMDM & Suryamas Dutamakmur Tbk. & 298 & ULTJ & Ultra Jaya Milk Industry \& Trading \\
\hline 259 & SMDR & Samudera Indonesia Tbk. & 299 & UNIC & Unggul Indah Cahaya Tbk. \\
\hline 260 & SMGR & Semen Indonesia (Persero) Tbk. & 300 & UNSP & Bakrie Sumatra Plantations Tbk. \\
\hline 261 & SMMT & Golden Eagle Energy Tbk. & 301 & UNTR & United Tractors Tbk. \\
\hline 262 & SMRA & Summarecon Agung Tbk. & 302 & UNVR & Unilever Indonesia Tbk. \\
\hline 263 & SMRU & SMR Utama Tbk. & 303 & VIVA & Visi Media Asia Tbk. \\
\hline 264 & SMSM & Selamat Sempurna Tbk. & 304 & VOKS & Voksel Electric Tbk. \\
\hline 265 & SONA & Sona Topas Tourism Industry Tbk. & 305 & WAPO & Wahana Pronatural Tbk. \\
\hline 266 & SPMA & Suparma Tbk. & 306 & WEHA & Weha Transportasi Indonesia Tbk. \\
\hline 267 & SRIL & Sri Rejeki Isman Tbk. & 307 & WIKA & Wijaya Karya Tbk. \\
\hline 268 & SRSN & Indo Acidatama Tbk & 308 & WINS & Wintermar Offshore Marine Tbk. \\
\hline 269 & SRTG & Saratoga Investama Sedaya Tbk. & 309 & WSKT & Waskita Karya (Persero) Tbk. \\
\hline 270 & SSIA & Surya Semesta Internusa Tbk. & 310 & WTON & Wijaya Karya Beton Tbk. \\
\hline 271 & STAR & Star Petrochem Tbk. & 311 & YPAS & Yanaprima Hastapersada Tbk \\
\hline 272 & SUGI & Sugih Energy Tbk. & 312 & ZBRA & Zebra Nusantara Tbk \\
\hline
\end{tabular}


Table A2. Data tabulation (source: authors' calculations)

\begin{tabular}{|c|c|c|c|c|c|c|c|c|c|c|}
\hline \multirow{2}{*}{ No } & \multirow{2}{*}{ Code } & \multicolumn{9}{|c|}{ Variables } \\
\hline & & CRD & EDU & SAC & MAC & RMC & AUD & STS & AGE & LEV \\
\hline 1 & ABMM & 0.4 & 1 & 3 & 9 & 0 & 1 & 1 & 1.10 & 0.82 \\
\hline 2 & ACST & 0.43 & 0 & 3 & 3 & 0 & 1 & 0 & 0.69 & 0.56 \\
\hline 3 & ADES & 0.23 & 1 & 3 & 3 & 0 & 0 & 1 & 3.04 & 0.41 \\
\hline 4 & ADHI & 0.43 & 0 & 2 & 11 & 1 & 0 & 0 & 2.40 & 0.83 \\
\hline 5 & $\mathrm{ADMG}$ & 0.23 & 1 & 3 & 4 & 0 & 1 & 0 & 3.04 & 0.37 \\
\hline 6 & ADRO & 0.6 & 1 & 3 & 6 & 0 & 1 & 0 & 1.79 & 0.49 \\
\hline 7 & AISA & 0.33 & 0 & 4 & 3 & 1 & 0 & 0 & 2.89 & 0.51 \\
\hline 8 & AKPI & 0.23 & 1 & 3 & 3 & 0 & 1 & 0 & 3.09 & 0.53 \\
\hline 9 & AKRA & 0.35 & 1 & 3 & 4 & 0 & 1 & 0 & 3.00 & 0.6 \\
\hline 10 & ALDO & 0.13 & 1 & 3 & 6 & 0 & 0 & 0 & 1.39 & 0.55 \\
\hline 11 & ALKA & 0.13 & 1 & 3 & 4 & 0 & 0 & 0 & 3.22 & 0.74 \\
\hline 12 & AMFG & 0.2 & 1 & 4 & 12 & 1 & 1 & 1 & 2.94 & 0.19 \\
\hline 13 & AMRT & 0.23 & 1 & 3 & 4 & 0 & 1 & 0 & 1.79 & 0.79 \\
\hline 14 & ANJT & 0.4 & 0 & 3 & 4 & 1 & 1 & 0 & 0.69 & 0.15 \\
\hline 15 & ANTM & 0.28 & 1 & 4 & 12 & 1 & 1 & 0 & 2.83 & 0.46 \\
\hline 16 & APEX & 0.33 & 1 & 3 & 5 & 0 & 1 & 0 & 0.69 & 0.97 \\
\hline 17 & APII & 0.2 & 0 & 3 & 5 & 0 & 0 & 1 & 0.00 & 0.52 \\
\hline 18 & APLN & 0.15 & 0 & 3 & 14 & 1 & 1 & 0 & 1.39 & 0.64 \\
\hline 19 & APOL & 0.33 & 1 & 3 & 3 & 0 & 0 & 0 & 2.20 & 3.25 \\
\hline 20 & ARII & 0.15 & 0 & 2 & 4 & 0 & 0 & 0 & 1.10 & 0.68 \\
\hline 21 & ARNA & 0.3 & 1 & 3 & 12 & 0 & 1 & 1 & 1.10 & 0.28 \\
\hline 22 & ARTI & 0.1 & 0 & 2 & 5 & 0 & 0 & 0 & 2.48 & 0.45 \\
\hline 23 & ASGR & 0.3 & 1 & 3 & 14 & 0 & 1 & 0 & 3.22 & 0.45 \\
\hline 24 & ASII & 0.13 & 0 & 4 & 7 & 0 & 1 & 0 & 3.22 & 0.49 \\
\hline 25 & ASRI & 0.18 & 1 & 3 & 6 & 0 & 0 & 0 & 1.95 & 0.62 \\
\hline 26 & ASSA & 0.4 & 1 & 3 & 5 & 0 & 1 & 0 & 0.69 & 0.67 \\
\hline 27 & ATPK & 0.23 & 1 & 3 & 4 & 0 & 0 & 1 & 2.56 & 0.35 \\
\hline 28 & AUTO & 0.1 & 1 & 3 & 6 & 0 & 1 & 0 & 2.83 & 0.3 \\
\hline 29 & BAPA & 0.18 & 0 & 3 & 2 & 0 & 0 & 0 & 1.95 & 0.43 \\
\hline 30 & BATA & 0.05 & 1 & 3 & 5 & 0 & 1 & 1 & 3.50 & 0.45 \\
\hline 31 & BBRM & 0.28 & 0 & 3 & 7 & 0 & 0 & 0 & 0.69 & 0.41 \\
\hline 32 & BCIP & 0.08 & 1 & 3 & 4 & 0 & 0 & 0 & 1.61 & 0.58 \\
\hline 33 & BEST & 0.23 & 1 & 3 & 7 & 0 & 0 & 0 & 1.10 & 0.22 \\
\hline 34 & BHIT & 0.15 & 1 & 3 & 4 & 0 & 1 & 0 & 2.83 & 0.53 \\
\hline 35 & BIMA & 0.25 & 1 & 3 & 8 & 0 & 0 & 0 & 3.00 & 2.86 \\
\hline 36 & BIPI & 0.2 & 1 & 3 & 8 & 0 & 0 & 0 & 1.61 & 0.66 \\
\hline 37 & BIPP & 0.25 & 0 & 3 & 4 & 0 & 0 & 0 & 2.94 & 0.27 \\
\hline 38 & BIRD & 0.1 & 0 & 3 & 2 & 0 & 0 & 0 & 0.00 & 0.5 \\
\hline 39 & BISI & 0.35 & 0 & 3 & 7 & 0 & 1 & 0 & 2.08 & 0.14 \\
\hline 40 & BKDP & 0.28 & 1 & 3 & 4 & 1 & 0 & 0 & 2.08 & 0.28 \\
\hline 41 & BKSL & 0.25 & 1 & 3 & 12 & 0 & 0 & 0 & 2.83 & 0.37 \\
\hline 42 & BLTA & 0.13 & 0 & 3 & 7 & 0 & 1 & 0 & 3.22 & 2.7 \\
\hline 43 & BLTZ & 0.35 & 0 & 3 & 3 & 0 & 0 & 0 & 0.00 & 0.21 \\
\hline
\end{tabular}




\begin{tabular}{|c|c|c|c|c|c|c|c|c|c|c|}
\hline \multirow{2}{*}{ No } & \multirow{2}{*}{ Code } & \multicolumn{9}{|c|}{ Variables } \\
\hline & & CRD & EDU & SAC & MAC & $\mathrm{RMC}$ & AUD & STS & AGE & LEV \\
\hline 44 & BMSR & 0.18 & 1 & 3 & 4 & 0 & 0 & 1 & 2.71 & 0.62 \\
\hline 45 & BMTR & 0.35 & 1 & 3 & 4 & 0 & 1 & 0 & 2.94 & 0.37 \\
\hline 46 & BNBR & 0.75 & 1 & 3 & 8 & 1 & 0 & 0 & 3.22 & 1.19 \\
\hline 47 & BRAM & 0.38 & 1 & 3 & 5 & 0 & 1 & 0 & 3.18 & 0.42 \\
\hline 48 & BRAU & 0.43 & 1 & 3 & 9 & 1 & 1 & 0 & 1.39 & 1.02 \\
\hline 49 & BRMS & 0.43 & 0 & 4 & 7 & 0 & 0 & 0 & 1.39 & 0.38 \\
\hline 50 & BRNA & 0.28 & 1 & 4 & 4 & 1 & 1 & 0 & 3.22 & 0.28 \\
\hline 51 & BSDE & 0.2 & 0 & 3 & 5 & 0 & 0 & 0 & 1.95 & 0.34 \\
\hline 52 & BTEK & 0.15 & 1 & 3 & 6 & 0 & 0 & 0 & 2.40 & 0.82 \\
\hline 53 & BTEL & 0.33 & 1 & 3 & 12 & 1 & 0 & 0 & 2.20 & 1.51 \\
\hline 54 & BTON & 0.15 & 0 & 3 & 5 & 0 & 0 & 0 & 2.56 & 0.16 \\
\hline 55 & BUDI & 0.15 & 0 & 3 & 4 & 0 & 0 & 0 & 3.00 & 0.63 \\
\hline 56 & BULL & 0.25 & 1 & 3 & 4 & 0 & 0 & 0 & 1.39 & 0.57 \\
\hline 57 & BUMI & 0.33 & 0 & 3 & 8 & 1 & 0 & 0 & 3.18 & 1.11 \\
\hline 58 & BWPT & 0.08 & 1 & 3 & 5 & 0 & 0 & 0 & 1.61 & 0.58 \\
\hline 59 & BYAN & 0.43 & 0 & 3 & 8 & 1 & 1 & 0 & 1.79 & 0.78 \\
\hline 60 & CASS & 0.25 & 1 & 3 & 4 & 0 & 0 & 0 & 1.10 & 0.55 \\
\hline 61 & CINT & 0.3 & 1 & 3 & 7 & 0 & 0 & 0 & 0.00 & 0.2 \\
\hline 62 & CKRA & 0.1 & 1 & 3 & 6 & 0 & 0 & 1 & 2.77 & 0.02 \\
\hline 63 & CMNP & 0.35 & 1 & 4 & 11 & 1 & 1 & 0 & 3.00 & 0.3 \\
\hline 64 & CMPP & 0.03 & 0 & 3 & 12 & 0 & 0 & 0 & 3.00 & 0.77 \\
\hline 65 & COWL & 0.25 & 0 & 3 & 4 & 0 & 0 & 0 & 1.95 & 0.63 \\
\hline 66 & CPGT & 0.1 & 1 & 3 & 5 & 0 & 0 & 0 & 0.69 & 0.76 \\
\hline 67 & CPIN & 0.15 & 1 & 5 & 32 & 0 & 1 & 1 & 3.53 & 0.48 \\
\hline 68 & CPRO & 0.03 & 1 & 3 & 12 & 0 & 1 & 0 & 2.08 & 0.87 \\
\hline 69 & CSAP & 0.23 & 0 & 3 & 4 & 0 & 1 & 0 & 1.95 & 0.75 \\
\hline 70 & CTBN & 0.23 & 1 & 3 & 4 & 0 & 1 & 0 & 3.22 & 0.44 \\
\hline 71 & CTRA & 0.13 & 1 & 3 & 4 & 0 & 1 & 0 & 3.04 & 0.51 \\
\hline 72 & CTRP & 0.23 & 1 & 3 & 5 & 1 & 1 & 0 & 1.95 & 0.45 \\
\hline 73 & CTRS & 0.2 & 1 & 3 & 4 & 0 & 1 & 0 & 2.77 & 0.51 \\
\hline 74 & СTTH & 0.18 & 0 & 3 & 6 & 0 & 0 & 0 & 2.94 & 0.78 \\
\hline 75 & DART & 0.15 & 1 & 3 & 12 & 1 & 1 & 1 & 3.22 & 0.37 \\
\hline 76 & DEWA & 0.45 & 1 & 3 & 11 & 0 & 0 & 1 & 1.95 & 0.27 \\
\hline 77 & DGIK & 0.15 & 0 & 3 & 5 & 0 & 0 & 0 & 1.95 & 0.46 \\
\hline 78 & DILD & 0.18 & 1 & 3 & 17 & 0 & 0 & 1 & 3.14 & 0.5 \\
\hline 79 & DKFT & 0.05 & 1 & 3 & 6 & 0 & 0 & 0 & 2.83 & 0.05 \\
\hline 80 & DLTA & 0.1 & 1 & 3 & 3 & 0 & 1 & 1 & 3.43 & 0.23 \\
\hline 81 & DOID & 0.23 & 1 & 3 & 4 & 0 & 0 & 1 & 1.39 & 0.9 \\
\hline 82 & DPNS & 0.18 & 1 & 3 & 4 & 0 & 0 & 0 & 3.18 & 0.12 \\
\hline 83 & DSFI & 0.23 & 1 & 3 & 8 & 0 & 0 & 0 & 2.71 & 0.56 \\
\hline 84 & DSNG & 0.2 & 0 & 3 & 5 & 0 & 1 & 0 & 0.69 & 0.68 \\
\hline 85 & DSSA & 0.43 & 1 & 3 & 9 & 0 & 0 & 0 & 1.61 & 0.36 \\
\hline 86 & DUTI & 0.25 & 1 & 3 & 5 & 0 & 0 & 0 & 3.00 & 0.22 \\
\hline 87 & DVLA & 0.25 & 0 & 4 & 4 & 0 & 1 & 1 & 3.00 & 0.24 \\
\hline
\end{tabular}




\begin{tabular}{|c|c|c|c|c|c|c|c|c|c|c|}
\hline \multirow{2}{*}{ No } & \multirow{2}{*}{ Code } & \multicolumn{9}{|c|}{ Variables } \\
\hline & & CRD & EDU & SAC & MAC & RMC & AUD & STS & AGE & LEV \\
\hline 88 & DYAN & 0.1 & 1 & 3 & 4 & 0 & 0 & 0 & 0.69 & 0.46 \\
\hline 89 & EKAD & 0.1 & 1 & 3 & 5 & 0 & 0 & 0 & 3.18 & 0.34 \\
\hline 90 & ELSA & 0.33 & 1 & 4 & 16 & 1 & 1 & 0 & 1.95 & 0.39 \\
\hline 91 & ELTY & 0.38 & 1 & 3 & 11 & 1 & 0 & 0 & 2.94 & 0.48 \\
\hline 92 & EMTK & 0.18 & 1 & 3 & 9 & 0 & 1 & 0 & 1.61 & 0.18 \\
\hline 93 & ENRG & 0.23 & 0 & 3 & 4 & 1 & 0 & 0 & 2.40 & 0.59 \\
\hline 94 & EPMT & 0.2 & 0 & 3 & 4 & 1 & 1 & 0 & 3.00 & 0.43 \\
\hline 95 & ERAA & 0.03 & 1 & 2 & 11 & 0 & 1 & 0 & 1.10 & 0.51 \\
\hline 96 & ERTX & 0.18 & 0 & 3 & 4 & 0 & 0 & 1 & 3.18 & 0.73 \\
\hline 97 & ESSA & 0.28 & 1 & 3 & 4 & 0 & 1 & 0 & 1.10 & 0.28 \\
\hline 98 & ETWA & 0.23 & 1 & 3 & 4 & 0 & 0 & 0 & 2.89 & 0.77 \\
\hline 99 & EXCL & 0.38 & 1 & 4 & 7 & 1 & 1 & 1 & 2.20 & 0.78 \\
\hline 100 & FASW & 0.15 & 0 & 3 & 14 & 0 & 1 & 0 & 3.00 & 0.71 \\
\hline 101 & FISH & 0.23 & 1 & 3 & 4 & 0 & 1 & 0 & 2.56 & 0.74 \\
\hline 102 & FMII & 0.2 & 1 & 2 & 5 & 0 & 0 & 1 & 2.71 & 0.38 \\
\hline 103 & FORU & 0.05 & 0 & 3 & 4 & 0 & 0 & 0 & 2.40 & 0.49 \\
\hline 104 & FPNI & 0.23 & 1 & 3 & 4 & 0 & 1 & 1 & 2.56 & 0.64 \\
\hline 105 & FREN & 0.28 & 1 & 3 & 3 & 0 & 0 & 0 & 2.08 & 0.78 \\
\hline 106 & GAMA & 0.08 & 1 & 3 & 3 & 0 & 0 & 0 & 1.10 & 0.21 \\
\hline 107 & GDST & 0.18 & 1 & 3 & 5 & 0 & 0 & 1 & 1.61 & 0.36 \\
\hline 108 & GDYR & 0.18 & 1 & 3 & 4 & 0 & 1 & 1 & 3.53 & 0.54 \\
\hline 109 & GEMA & 0.1 & 1 & 3 & 4 & 0 & 0 & 0 & 2.48 & 0.6 \\
\hline 110 & GEMS & 0.28 & 1 & 3 & 5 & 0 & 1 & 0 & 1.10 & 0.21 \\
\hline 111 & GGRM & 0.15 & 0 & 3 & 6 & 0 & 1 & 0 & 3.18 & 0.43 \\
\hline 112 & GIAA & 0.4 & 1 & 3 & 31 & 1 & 1 & 0 & 1.39 & 0.7 \\
\hline 113 & GJTL & 0.18 & 1 & 3 & 11 & 0 & 1 & 0 & 3.22 & 0.63 \\
\hline 114 & GLOB & 0.13 & 1 & 3 & 4 & 0 & 1 & 0 & 1.10 & 0.69 \\
\hline 115 & GMCW & 0.25 & 1 & 3 & 5 & 0 & 0 & 0 & 3.00 & 0.82 \\
\hline 116 & GMTD & 0.3 & 1 & 3 & 4 & 0 & 0 & 0 & 2.64 & 0.56 \\
\hline 117 & GOLD & 0.28 & 1 & 2 & 4 & 0 & 0 & 0 & 1.61 & 0.15 \\
\hline 118 & GPRA & 0.2 & 1 & 3 & 4 & 0 & 0 & 0 & 1.95 & 0.41 \\
\hline 119 & GREN & 0.18 & 1 & 3 & 4 & 0 & 0 & 1 & 1.61 & 0.27 \\
\hline 120 & GWSA & 0.33 & 1 & 3 & 4 & 0 & 1 & 0 & 1.10 & 0.14 \\
\hline 121 & HDTX & 0.18 & 1 & 3 & 13 & 0 & 0 & 0 & 3.22 & 0.85 \\
\hline 122 & HERO & 0.15 & 1 & 3 & 12 & 0 & 1 & 0 & 3.22 & 0.34 \\
\hline 123 & HMSP & 0.23 & 1 & 3 & 3 & 0 & 1 & 1 & 3.18 & 0.52 \\
\hline 124 & HRUM & 0.35 & 1 & 3 & 5 & 0 & 1 & 0 & 0.69 & 0.18 \\
\hline 125 & IATA & 0.25 & 1 & 3 & 6 & 0 & 0 & 0 & 2.08 & 0.47 \\
\hline 126 & IBST & 0.28 & 1 & 3 & 8 & 0 & 0 & 0 & 0.69 & 0.21 \\
\hline 127 & ICBP & 0.2 & 1 & 3 & 6 & 0 & 1 & 0 & 1.39 & 0.4 \\
\hline 128 & ICON & 0.08 & 1 & 3 & 2 & 0 & 0 & 0 & 2.30 & 0.45 \\
\hline 129 & IGAR & 0.13 & 0 & 3 & 4 & 0 & 0 & 0 & 3.18 & 0.25 \\
\hline 130 & IIKP & 0.15 & 0 & 3 & 4 & 0 & 0 & 0 & 2.48 & 0.04 \\
\hline 131 & IMAS & 0.15 & 1 & 3 & 6 & 0 & 1 & 0 & 3.04 & 0.71 \\
\hline
\end{tabular}




\begin{tabular}{|c|c|c|c|c|c|c|c|c|c|c|}
\hline \multirow{2}{*}{ No } & \multirow{2}{*}{ Code } & \multicolumn{9}{|c|}{ Variables } \\
\hline & & CRD & EDU & SAC & MAC & RMC & AUD & STS & AGE & LEV \\
\hline 132 & INAF & 0.23 & 1 & 3 & 16 & 1 & 0 & 0 & 2.64 & 0.53 \\
\hline 133 & INCO & 0.3 & 1 & 4 & 5 & 0 & 1 & 1 & 3.22 & 0.24 \\
\hline 134 & INDF & 0.2 & 1 & 3 & 9 & 0 & 1 & 1 & 3.04 & 0.52 \\
\hline 135 & INDR & 0.13 & 1 & 3 & 4 & 0 & 1 & 1 & 3.18 & 0.59 \\
\hline 136 & INDS & 0.13 & 1 & 3 & 5 & 0 & 0 & 0 & 3.18 & 0.2 \\
\hline 137 & INDX & 0.05 & 1 & 3 & 1 & 0 & 0 & 1 & 2.64 & 0.03 \\
\hline 138 & INDY & 0.28 & 1 & 3 & 4 & 1 & 1 & 0 & 1.61 & 0.6 \\
\hline 139 & INKP & 0.2 & 0 & 3 & 9 & 0 & 0 & 0 & 3.18 & 0.63 \\
\hline 140 & INPP & 0.13 & 1 & 3 & 4 & 0 & 0 & 0 & 2.30 & 0.46 \\
\hline 141 & INRU & 0.13 & 1 & 3 & 2 & 0 & 0 & 1 & 3.22 & 0.61 \\
\hline 142 & INTA & 0.23 & 1 & 3 & 6 & 0 & 1 & 0 & 3.04 & 0.84 \\
\hline 143 & INTD & 0.15 & 1 & 3 & 4 & 0 & 0 & 0 & 3.22 & 0.47 \\
\hline 144 & INTP & 0.18 & 1 & 3 & 4 & 0 & 1 & 1 & 3.22 & 0.14 \\
\hline 145 & IPOL & 0.33 & 1 & 3 & 5 & 0 & 0 & 1 & 1.61 & 0.46 \\
\hline 146 & ISAT & 0.9 & 0 & 5 & 5 & 1 & 1 & 0 & 3.00 & 0.73 \\
\hline 147 & ITMG & 0.33 & 1 & 3 & 12 & 1 & 1 & 1 & 1.95 & 0.31 \\
\hline 148 & ITTG & 0.05 & 0 & 3 & 3 & 0 & 0 & 0 & 2.56 & 0.04 \\
\hline 149 & JAWA & 0.13 & 1 & 3 & 5 & 0 & 0 & 0 & 1.39 & 0.57 \\
\hline 150 & JECC & 0.1 & 0 & 3 & 17 & 0 & 0 & 0 & 3.09 & 0.84 \\
\hline 151 & JIHD & 0.08 & 1 & 3 & 7 & 0 & 0 & 0 & 3.43 & 0.28 \\
\hline 152 & JKSW & 0.15 & 1 & 3 & 6 & 0 & 0 & 0 & 2.83 & 2.38 \\
\hline 153 & JPFA & 0.2 & 0 & 3 & 4 & 0 & 0 & 1 & 3.22 & 0.66 \\
\hline 154 & JPRS & 0.25 & 1 & 3 & 12 & 0 & 0 & 1 & 3.22 & 0.04 \\
\hline 155 & JSMR & 0.4 & 1 & 3 & 17 & 1 & 0 & 0 & 1.95 & 0.64 \\
\hline 156 & JTPE & 0.18 & 0 & 3 & 4 & 0 & 0 & 0 & 2.56 & 0.57 \\
\hline 157 & KBLI & 0.25 & 1 & 3 & 4 & 0 & 1 & 0 & 3.14 & 0.3 \\
\hline 158 & KBLM & 0.13 & 1 & 3 & 3 & 0 & 0 & 0 & 3.14 & 0.55 \\
\hline 159 & KBLV & 0.03 & 0 & 3 & 4 & 0 & 0 & 0 & 2.71 & 0.28 \\
\hline 160 & KBRI & 0.25 & 1 & 3 & 5 & 0 & 0 & 0 & 1.95 & 0.48 \\
\hline 161 & KIAS & 0.28 & 0 & 3 & 6 & 0 & 0 & 1 & 3.00 & 0.1 \\
\hline 162 & KICI & 0.18 & 0 & 3 & 4 & 0 & 0 & 0 & 3.04 & 0.19 \\
\hline 163 & KIJA & 0.15 & 0 & 3 & 9 & 0 & 0 & 0 & 3.00 & 0.45 \\
\hline 164 & KKGI & 0.15 & 0 & 3 & 5 & 0 & 0 & 0 & 3.18 & 0.27 \\
\hline 165 & KLBF & 0.4 & 0 & 3 & 4 & 1 & 1 & 0 & 3.14 & 0.21 \\
\hline 166 & KOBX & 0.1 & 0 & 3 & 5 & 0 & 0 & 0 & 1.10 & 0.68 \\
\hline 167 & KOIN & 0.2 & 1 & 3 & 6 & 0 & 0 & 0 & 1.95 & 0.78 \\
\hline 168 & KPIG & 0.33 & 1 & 3 & 4 & 0 & 0 & 0 & 2.71 & 0.2 \\
\hline 169 & KRAH & 0.43 & 0 & 3 & 4 & 0 & 0 & 0 & 0.00 & 0.61 \\
\hline 170 & KRAS & 0.4 & 1 & 4 & 21 & 1 & 1 & 0 & 1.39 & 0.66 \\
\hline 171 & LCGP & 0.25 & 1 & 3 & 4 & 0 & 0 & 0 & 2.08 & 0.07 \\
\hline 172 & LEAD & 0.3 & 1 & 3 & 5 & 1 & 1 & 0 & 0.00 & 0.5 \\
\hline 173 & LION & 0.15 & 1 & 3 & 3 & 0 & 0 & 1 & 3.04 & 0.26 \\
\hline 174 & LMPI & 0.1 & 0 & 3 & 12 & 0 & 0 & 0 & 3.00 & 0.51 \\
\hline 175 & LMSH & 0.25 & 0 & 3 & 4 & 0 & 0 & 0 & 3.22 & 0.17 \\
\hline
\end{tabular}




\begin{tabular}{|c|c|c|c|c|c|c|c|c|c|c|}
\hline \multirow{2}{*}{ No } & \multirow{2}{*}{ Code } & \multicolumn{9}{|c|}{ Variables } \\
\hline & & CRD & EDU & SAC & MAC & $\mathrm{RMC}$ & AUD & STS & AGE & LEV \\
\hline 176 & LPCK & 0.18 & 0 & 3 & 4 & 0 & 0 & 0 & 2.83 & 0.38 \\
\hline 177 & LPIN & 0.15 & 1 & 3 & 3 & 0 & 0 & 0 & 3.22 & 0.25 \\
\hline 178 & LPKR & 0.5 & 1 & 3 & 4 & 0 & 0 & 0 & 2.94 & 0.53 \\
\hline 179 & LPLI & 0.13 & 1 & 3 & 4 & 0 & 0 & 0 & 3.22 & 0.05 \\
\hline 180 & LPPF & 0.23 & 1 & 3 & 4 & 1 & 1 & 1 & 3.22 & 0.95 \\
\hline 181 & LRNA & 0.23 & 0 & 3 & 2 & 0 & 0 & 0 & 0.00 & 0.24 \\
\hline 182 & LSIP & 0.33 & 1 & 3 & 4 & 0 & 1 & 0 & 2.94 & 0.17 \\
\hline 183 & MAIN & 0.03 & 1 & 5 & 4 & 0 & 1 & 1 & 2.20 & 0.69 \\
\hline 184 & MAMI & 0.05 & 1 & 3 & 5 & 0 & 0 & 0 & 3.04 & 0.22 \\
\hline 185 & MBAP & 0.15 & 0 & 3 & 2 & 0 & 1 & 0 & 0.00 & 0.43 \\
\hline 186 & MBSS & 0.28 & 1 & 4 & 4 & 1 & 1 & 0 & 1.39 & 0.28 \\
\hline 187 & MBTO & 0.2 & 1 & 2 & 37 & 0 & 0 & 0 & 1.39 & 0.27 \\
\hline 188 & MDLN & 0.28 & 1 & 3 & 9 & 0 & 0 & 0 & 3.09 & 0.49 \\
\hline 189 & MDRN & 0.28 & 1 & 3 & 12 & 0 & 1 & 0 & 3.14 & 0.43 \\
\hline 190 & MEDC & 0.3 & 0 & 3 & 5 & 1 & 1 & 1 & 3.00 & 0.66 \\
\hline 191 & META & 0.1 & 1 & 3 & 7 & 0 & 0 & 1 & 2.56 & 0.42 \\
\hline 192 & MFMI & 0.05 & 1 & 3 & 4 & 0 & 0 & 0 & 1.39 & 0.07 \\
\hline 193 & MICE & 0.08 & 1 & 3 & 6 & 0 & 0 & 0 & 2.20 & 0.2 \\
\hline 194 & MIDI & 0.33 & 1 & 3 & 4 & 0 & 1 & 0 & 1.39 & 0.76 \\
\hline 195 & MKPI & 0.23 & 0 & 3 & 4 & 0 & 0 & 0 & 1.79 & 0.5 \\
\hline 196 & MLBI & 0.13 & 1 & 3 & 5 & 0 & 1 & 1 & 3.04 & 0.75 \\
\hline 197 & MLIA & 0.18 & 1 & 3 & 12 & 0 & 1 & 0 & 3.04 & 0.82 \\
\hline 198 & MLPL & 0.13 & 1 & 3 & 4 & 0 & 0 & 0 & 3.22 & 0.55 \\
\hline 199 & MLPT & 0.3 & 1 & 3 & 4 & 0 & 0 & 0 & 0.69 & 0.65 \\
\hline 200 & MNCN & 0.35 & 1 & 3 & 4 & 0 & 1 & 0 & 2.08 & 0.31 \\
\hline 201 & MPMX & 0.1 & 1 & 3 & 7 & 0 & 1 & 0 & 0.69 & 0.62 \\
\hline 202 & MPPA & 0.18 & 1 & 4 & 4 & 0 & 0 & 0 & 3.09 & 0.51 \\
\hline 203 & MRAT & 0.18 & 1 & 3 & 3 & 0 & 0 & 0 & 2.94 & 0.23 \\
\hline 204 & MSKY & 0.33 & 1 & 3 & 4 & 0 & 1 & 0 & 1.10 & 0.73 \\
\hline 205 & MTDL & 0.18 & 1 & 3 & 5 & 0 & 1 & 0 & 3.22 & 0.57 \\
\hline 206 & MTLA & 0.4 & 0 & 3 & 4 & 0 & 1 & 1 & 1.39 & 0.37 \\
\hline 207 & $\mathrm{MYOH}$ & 0.15 & 1 & 3 & 5 & 0 & 1 & 1 & 2.64 & 0.79 \\
\hline 208 & MYOR & 0.25 & 0 & 3 & 5 & 0 & 0 & 0 & 3.22 & 0.6 \\
\hline 209 & MYRX & 0.18 & 1 & 3 & 6 & 0 & 1 & 0 & 3.18 & 0.15 \\
\hline 210 & NELY & 0.15 & 0 & 3 & 10 & 0 & 0 & 0 & 0.69 & 0.23 \\
\hline 211 & NIKL & 0.38 & 1 & 4 & 7 & 0 & 1 & 0 & 1.61 & 0.71 \\
\hline 212 & NIRO & 0.23 & 1 & 3 & 5 & 0 & 0 & 0 & 0.69 & 0.43 \\
\hline 213 & NRCA & 0.3 & 0 & 3 & 4 & 0 & 0 & 0 & 0.69 & 0.46 \\
\hline 214 & OKAS & 0.3 & 1 & 4 & 7 & 1 & 1 & 0 & 2.20 & 0.85 \\
\hline 215 & PALM & 0.18 & 1 & 3 & 7 & 0 & 0 & 0 & 0.69 & 0.6 \\
\hline 216 & PBRX & 0.08 & 1 & 3 & 10 & 0 & 0 & 0 & 3.18 & 0.44 \\
\hline 217 & PDES & 0.03 & 1 & 3 & 2 & 0 & 0 & 0 & 1.95 & 0.49 \\
\hline 218 & PGAS & 0.33 & 1 & 5 & 44 & 1 & 1 & 0 & 2.40 & 0.52 \\
\hline 219 & PGLI & 0.18 & 1 & 3 & 28 & 0 & 0 & 0 & 2.71 & 0.18 \\
\hline
\end{tabular}




\begin{tabular}{|c|c|c|c|c|c|c|c|c|c|c|}
\hline \multirow{2}{*}{ No } & \multirow{2}{*}{ Code } & \multicolumn{9}{|c|}{ Variables } \\
\hline & & CRD & EDU & SAC & MAC & RMC & AUD & STS & AGE & LEV \\
\hline 220 & PJAA & 0.18 & 0 & 3 & 48 & 0 & 0 & 0 & 2.40 & 0.44 \\
\hline 221 & PKPK & 0.08 & 0 & 3 & 3 & 0 & 0 & 0 & 2.08 & 0.52 \\
\hline 222 & PLAS & 0.2 & 1 & 3 & 3 & 0 & 0 & 0 & 2.64 & 0.35 \\
\hline 223 & PLIN & 0.18 & 1 & 3 & 48 & 0 & 1 & 0 & 3.14 & 0.48 \\
\hline 224 & PNSE & 0.38 & 0 & 3 & 9 & 0 & 0 & 0 & 3.22 & 0.33 \\
\hline 225 & POOL & 0.23 & 1 & 3 & 6 & 0 & 1 & 0 & 3.18 & 0.14 \\
\hline 226 & PRAS & 0.2 & 0 & 3 & 4 & 0 & 0 & 0 & 3.22 & 0.47 \\
\hline 227 & PSKT & 0.2 & 1 & 3 & 3 & 0 & 0 & 0 & 2.94 & 0.58 \\
\hline 228 & PTBA & 0.48 & 0 & 4 & 59 & 1 & 1 & 0 & 0.00 & 0.41 \\
\hline 229 & РТРP & 0.4 & 0 & 4 & 27 & 0 & 0 & 0 & 1.61 & 0.84 \\
\hline 230 & PTRO & 0.13 & 1 & 3 & 4 & 1 & 1 & 1 & 3.22 & 0.59 \\
\hline 231 & PTSP & 0.03 & 0 & 3 & 12 & 0 & 0 & 1 & 3,04 & 0,45 \\
\hline 232 & PUDP & 0,35 & 1 & 3 & 4 & 0 & 0 & 0 & 3.00 & 0.28 \\
\hline 233 & PWON & 0.23 & 0 & 3 & 5 & 0 & 1 & 0 & 3.22 & 0.51 \\
\hline 234 & RAJA & 0.2 & 1 & 3 & 4 & 1 & 0 & 0 & 2.20 & 0.52 \\
\hline 235 & RALS & 0.2 & 1 & 4 & 4 & 0 & 1 & 0 & 2.89 & 0.26 \\
\hline 236 & RANC & 0.3 & 1 & 3 & 3 & 0 & 0 & 0 & 1.10 & 0.48 \\
\hline 237 & RBMS & 0.13 & 0 & 3 & 24 & 0 & 0 & 0 & 2.83 & 0.15 \\
\hline 238 & RICY & 0.2 & 1 & 3 & 4 & 0 & 0 & 0 & 2.83 & 0.66 \\
\hline 239 & RMBA & 0.1 & 1 & 3 & 4 & 0 & 1 & 0 & 3.22 & 1.14 \\
\hline 240 & RODA & 0.3 & 1 & 3 & 4 & 0 & 0 & 0 & 2.56 & 0.31 \\
\hline 241 & ROTI & 0.23 & 1 & 4 & 4 & 0 & 1 & 1 & 1.61 & 0.55 \\
\hline 242 & RUIS & 0.23 & 1 & 3 & 12 & 0 & 0 & 0 & 2.20 & 0.75 \\
\hline 243 & SAFE & 0.25 & 1 & 3 & 3 & 0 & 0 & 0 & 3.00 & 7.69 \\
\hline 244 & SCMA & 0.23 & 1 & 3 & 12 & 0 & 1 & 0 & 2.48 & 0.26 \\
\hline 245 & SDMU & 0.08 & 0 & 3 & 10 & 0 & 0 & 0 & 1.39 & 0.48 \\
\hline 246 & SDPC & 0.1 & 1 & 4 & 4 & 1 & 0 & 0 & 3.22 & 0.77 \\
\hline 247 & SGRO & 0.3 & 1 & 3 & 4 & 1 & 1 & 0 & 2.08 & 0.45 \\
\hline 248 & SIAP & 0.08 & 0 & 3 & 1 & 0 & 0 & 0 & 1.79 & 0.04 \\
\hline 249 & SILO & 0.33 & 1 & 3 & 4 & 0 & 0 & 0 & 0.00 & 0.42 \\
\hline 250 & SIMP & 0.35 & 1 & 3 & 9 & 0 & 1 & 1 & 1.39 & 0.46 \\
\hline 251 & SIPD & 0.2 & 1 & 3 & 4 & 0 & 0 & 0 & 2.89 & 0.54 \\
\hline 252 & SKBM & 0.18 & 1 & 3 & 4 & 0 & 0 & 0 & 0.69 & 0.51 \\
\hline 253 & SKLT & 0.1 & 1 & 3 & 4 & 0 & 0 & 0 & 3.43 & 0.54 \\
\hline 254 & SKYB & 0.2 & 1 & 3 & 5 & 0 & 0 & 1 & 1.61 & 0.6 \\
\hline 255 & SMAR & 0.33 & 1 & 3 & 11 & 0 & 0 & 0 & 3.09 & 0.63 \\
\hline 256 & SMBR & 0.38 & 0 & 3 & 4 & 0 & 0 & 0 & 0.69 & 0.07 \\
\hline 257 & SMCB & 0.05 & 1 & 3 & 5 & 0 & 1 & 1 & 2.83 & 0.49 \\
\hline 258 & SMDM & 0.23 & 0 & 3 & 4 & 0 & 0 & 1 & 2.94 & 0.3 \\
\hline 259 & SMDR & 0.15 & 0 & 3 & 8 & 0 & 1 & 0 & 2.71 & 0.53 \\
\hline 260 & SMGR & 0.43 & 0 & 5 & 12 & 1 & 1 & 0 & 3.18 & 0.27 \\
\hline 261 & SMMT & 0.18 & 1 & 3 & 4 & 0 & 1 & 1 & 2.48 & 0.37 \\
\hline 262 & SMRA & 0.25 & 1 & 3 & 4 & 0 & 1 & 0 & 3.22 & 0.61 \\
\hline 263 & SMRU & 0.1 & 1 & 3 & 2 & 0 & 0 & 0 & 1.10 & 0.5 \\
\hline
\end{tabular}




\begin{tabular}{|c|c|c|c|c|c|c|c|c|c|c|}
\hline \multirow{2}{*}{ No } & \multirow{2}{*}{ Code } & \multicolumn{9}{|c|}{ Variables } \\
\hline & & CRD & EDU & SAC & MAC & RMC & AUD & STS & AGE & LEV \\
\hline 264 & SMSM & 0.2 & 0 & 3 & 4 & 0 & 1 & 0 & 2.89 & 0.34 \\
\hline 265 & SONA & 0.25 & 1 & 3 & 4 & 0 & 0 & 0 & 3.14 & 0.4 \\
\hline 266 & SPMA & 0.2 & 0 & 3 & 5 & 0 & 0 & 0 & 3.00 & 0.62 \\
\hline 267 & SRIL & 0.08 & 1 & 3 & 3 & 0 & 0 & 0 & 0.69 & 0.67 \\
\hline 268 & SRSN & 0.13 & 0 & 4 & 6 & 0 & 0 & 0 & 3.09 & 0.29 \\
\hline 269 & SRTG & 0.35 & 1 & 3 & 11 & 0 & 1 & 0 & 0.69 & 0.29 \\
\hline 270 & SSIA & 0.2 & 1 & 3 & 8 & 0 & 0 & 0 & 2.89 & 0.49 \\
\hline 271 & STAR & 0.05 & 1 & 3 & 5 & 0 & 0 & 0 & 1.39 & 0.37 \\
\hline 272 & SUGI & 0.2 & 1 & 3 & 4 & 0 & 0 & 1 & 2.56 & 0.45 \\
\hline 273 & SULI & 0.2 & 1 & 3 & 12 & 0 & 1 & 0 & 3.04 & 1.41 \\
\hline 274 & TALF & 0.23 & 0 & 3 & 4 & 0 & 0 & 0 & 0.00 & 0.24 \\
\hline 275 & TAXI & 0.08 & 1 & 3 & 4 & 0 & 0 & 0 & 0.69 & 0.7 \\
\hline 276 & TBIG & 0.23 & 0 & 3 & 5 & 0 & 0 & 0 & 1.39 & 0.81 \\
\hline 277 & TBMS & 0.15 & 0 & 3 & 4 & 0 & 1 & 1 & 3.04 & 0.89 \\
\hline 278 & TCID & 0.2 & 1 & 4 & 14 & 0 & 1 & 1 & 3.04 & 0.31 \\
\hline 279 & TELE & 0.2 & 1 & 3 & 4 & 0 & 0 & 0 & 1.10 & 0.5 \\
\hline 280 & TFCO & 0.1 & 0 & 3 & 4 & 0 & 1 & 1 & 3.56 & 0.15 \\
\hline 281 & TGKA & 0.28 & 1 & 3 & 4 & 0 & 1 & 0 & 3.22 & 0.7 \\
\hline 282 & TINS & 0.4 & 0 & 4 & 3 & 1 & 1 & 0 & 2.94 & 0.42 \\
\hline 283 & TIRA & 0.05 & 1 & 3 & 5 & 0 & 0 & 0 & 3.04 & 0.61 \\
\hline 284 & TKIM & 0.2 & 0 & 3 & 9 & 0 & 0 & 0 & 3.22 & 0.66 \\
\hline 285 & TLKM & 0.63 & 0 & 6 & 38 & 1 & 1 & 0 & 2.94 & 0.39 \\
\hline 286 & TMAS & 0.15 & 0 & 3 & 12 & 0 & 1 & 0 & 2.48 & 0.67 \\
\hline 287 & ТОВА & 0.2 & 1 & 3 & 9 & 0 & 1 & 0 & 1.10 & 0.53 \\
\hline 288 & TOTL & 0.3 & 1 & 3 & 10 & 0 & 0 & 0 & 2.08 & 0.68 \\
\hline 289 & тото & 0.18 & 1 & 3 & 12 & 1 & 1 & 1 & 3.18 & 0.39 \\
\hline 290 & TOWR & 0.35 & 1 & 3 & 4 & 0 & 1 & 0 & 1.61 & 0.73 \\
\hline 291 & TPIA & 0.3 & 1 & 3 & 12 & 0 & 1 & 0 & 1.95 & 0.55 \\
\hline 292 & TPMA & 0.05 & 0 & 3 & 4 & 0 & 0 & 0 & 0.69 & 0.54 \\
\hline 293 & TRAM & 0.28 & 1 & 3 & 4 & 0 & 0 & 0 & 1.79 & 0.63 \\
\hline 294 & TRIO & 0.28 & 1 & 3 & 6 & 0 & 1 & 0 & 1.79 & 0.74 \\
\hline 295 & TRIS & 0.33 & 1 & 3 & 9 & 0 & 0 & 0 & 1.10 & 0.41 \\
\hline 296 & TRST & 0.15 & 0 & 3 & 4 & 0 & 1 & 0 & 3.22 & 0.46 \\
\hline 297 & TURI & 0.2 & 1 & 4 & 4 & 0 & 1 & 0 & 3.00 & 0.46 \\
\hline 298 & ULTJ & 0.25 & 1 & 3 & 3 & 0 & 0 & 0 & 3.22 & 0.22 \\
\hline 299 & UNIC & 0.15 & 0 & 3 & 6 & 0 & 1 & 1 & 3.22 & 0.39 \\
\hline 300 & UNSP & 0.4 & 1 & 3 & 4 & 1 & 0 & 0 & 3.22 & 0.76 \\
\hline 301 & UNTR & 0.28 & 0 & 3 & 4 & 0 & 1 & 0 & 3.22 & 0.36 \\
\hline 302 & UNVR & 0.18 & 1 & 3 & 4 & 0 & 1 & 1 & 3.50 & 0.68 \\
\hline 303 & VIVA & 0.13 & 1 & 3 & 2 & 1 & 0 & 0 & 1.10 & 0.57 \\
\hline 304 & VOKS & 0.13 & 0 & 3 & 6 & 0 & 1 & 1 & 3.18 & 0.67 \\
\hline 305 & WAPO & 0.23 & 1 & 3 & 4 & 0 & 0 & 0 & 2.64 & 0.86 \\
\hline 306 & WEHA & 0.3 & 1 & 3 & 2 & 0 & 0 & 0 & 2.08 & 0.66 \\
\hline 307 & WIKA & 0.15 & 1 & 6 & 18 & 0 & 0 & 0 & 2.30 & 0.69 \\
\hline
\end{tabular}




\begin{tabular}{|c|c|c|c|c|c|c|c|c|c|c|}
\hline \multirow{2}{*}{ No } & \multirow{2}{*}{ Code } & \multicolumn{9}{|c|}{ Variables } \\
\cline { 3 - 11 } & & CRD & EDU & SAC & MAC & RMC & AUD & STS & AGE & LEV \\
\hline 308 & WINS & 0.18 & 0 & 3 & 11 & 0 & 0 & 0 & 1.39 & 0.47 \\
\hline 309 & WSKT & 0.2 & 1 & 4 & 22 & 1 & 0 & 0 & 0.69 & 0.77 \\
\hline 310 & WTON & 0.23 & 0 & 4 & 4 & 0 & 0 & 0 & 0.00 & 0.41 \\
\hline 311 & YPAS & 0.2 & 0 & 3 & 4 & 0 & 0 & 0 & 1.95 & 0.49 \\
\hline 312 & ZBRA & 0.05 & 0 & 3 & 3 & 0 & 0 & 0 & 3.14 & 0.38 \\
\hline
\end{tabular}

Table A3. Big four accounting firms and affiliations in Indonesia

\begin{tabular}{|c|l|l|}
\hline No & \multicolumn{1}{|c|}{ Big Four Accounting Firms } & \multicolumn{1}{c|}{ Affiliation in Indonesia } \\
\hline 1 & Deloitte Touche & KAP Osman Bing Satrio \& Eny \\
\hline 2 & PricewaterhouseCoopers (PWC) & KAP Tanudiredja, Wibisana, Rintis \& Rekan \\
\hline 3 & Ernst \& Young (EY) & KAP Purwantono, Suherman \& Surja \\
\hline 4 & Klynveld Peat Marwick Goerdeler (KPMG) & KAP Sidharta \&Widjaja \\
\hline
\end{tabular}

Table A4. Descriptive statistics (source: authors' calculations)

\begin{tabular}{|c|c|c|c|c|c|}
\hline & $\mathrm{N}$ & Minimum & Maximum & Mean & Std. Deviation \\
\hline CRD & 312 & .03 & .90 & .2225 & .11593 \\
\hline SAC & 312 & 2.00 & 6.00 & 3.1154 & .46707 \\
\hline MAC & 312 & 1.00 & 59.00 & 7.1346 & 7.07887 \\
\hline AGE & 312 & 1.00 & 35.00 & 13.7147 & 8.97829 \\
\hline LEV & 312 & .02 & 7.69 & .5406 & .53590 \\
\hline Valid N (listwise) & 312 & & & & \\
\hline
\end{tabular}

Table A4. Statistics of educational background (source: authors' calculations)

\begin{tabular}{|c|l|c|c|c|c|}
\hline \multicolumn{2}{|c|}{} & Frequency & Percent & Valid Percent & Cumulative Percent \\
\hline \multirow{3}{*}{ Valid } & Otherwise & 97 & 31.1 & 31.1 & 31.1 \\
\cline { 2 - 7 } & Bisiness/Finance & 215 & 68.9 & 68.9 & 100.0 \\
\cline { 2 - 7 } & Total & 312 & 100.0 & 100.0 & \\
\hline
\end{tabular}

Table A5. Statistics of the existence of risk monitoring committee (source: authors' calculations)

\begin{tabular}{|c|c|c|c|c|c|}
\hline \multirow{2}{*}{} & Frequency & Percent & Valid Percent & Cumulative Percent \\
\hline \multirow{3}{*}{ Valid } & No & 265 & 84.9 & 84.9 & 84.9 \\
\cline { 2 - 6 } & Yes & 47 & 15.1 & 15.1 & 100.0 \\
\cline { 2 - 6 } & Total & 312 & 100.0 & 100.0 & \\
\hline
\end{tabular}

Table A6. Statistics of external auditor quality (source: authors' calculations)

\begin{tabular}{|c|l|c|c|c|c|}
\hline \multicolumn{2}{|c|}{} & Frequency & Percent & Valid Percent & Cumulative Percent \\
\hline \multirow{3}{*}{ Valid } & Non-Big Four & 184 & 59.0 & 59.0 & 59.0 \\
\cline { 2 - 7 } & Big Four & 128 & 41.0 & 41.0 & 100.0 \\
\cline { 2 - 7 } & Total & 312 & 100.0 & 100.0 & \\
\hline
\end{tabular}

Table A7. Statistics of firm status (source: authors' calculations)

\begin{tabular}{|c|l|c|c|c|c|}
\hline \multicolumn{2}{|c|}{} & Frequency & Percent & Valid Percent & Cumulative Percent \\
\hline \multirow{3}{*}{ Valid } & Otherwise & 253 & 81.1 & 81.1 & 81.1 \\
\cline { 2 - 7 } & Foreign ownership & 59 & 18.9 & 18.9 & 100.0 \\
\cline { 2 - 7 } & Total & 312 & 100.0 & 100.0 & \\
\hline
\end{tabular}


Table A8. Normality tests of residuals (source: authors' calculations)

\begin{tabular}{|c|c|c|}
\hline & & Unstandardized Residual \\
\hline \multicolumn{2}{|c|}{$\mathrm{N}$} & 312 \\
\hline \multirow{2}{*}{ Normal Parameters ${ }^{\mathrm{a}, \mathrm{b}}$} & Mean & .0000000 \\
\hline & Std. Deviation & .10205451 \\
\hline \multirow{3}{*}{ Most Extreme Differences } & Absolute & .042 \\
\hline & Positive & .042 \\
\hline & Negative & -.028 \\
\hline \multicolumn{2}{|l|}{ Test Statistic } & .042 \\
\hline \multicolumn{2}{|l|}{ Asymp. Sig. (2-tailed) } & $.200^{\mathrm{c}, \mathrm{d}}$ \\
\hline \multicolumn{3}{|l|}{ a. Test distribution is Normal. } \\
\hline \multicolumn{3}{|l|}{ b. Calculated from data. } \\
\hline \multicolumn{2}{|c|}{$\begin{array}{l}\text { c. Lilliefors Significance Correction } \\
\text { d. This is a lower bound of the true significance }\end{array}$} & \\
\hline
\end{tabular}

Table A9. Collinearity Diagnostics (source: authors' calculations)

\begin{tabular}{|c|c|c|c|}
\hline \multirow{2}{*}{} & \multicolumn{2}{|c|}{ Collinearity Statistics } \\
\cline { 2 - 4 } & \multirow{3}{*}{ Model } & Tolerance & VIF \\
\cline { 2 - 4 } & (Constant) & & 1.028 \\
\cline { 2 - 4 } & EDU & .973 & 1.221 \\
\cline { 2 - 4 } & SAC & .819 & 1.136 \\
\cline { 2 - 4 } & MAC & .880 & 1.181 \\
\cline { 2 - 4 } & RMC & .847 & 1.144 \\
\cline { 2 - 4 } & AUD & .874 & 1.089 \\
\cline { 2 - 4 } & STS & .918 & 1.055 \\
\cline { 2 - 4 } & AGE & .948 & 1.019 \\
\hline
\end{tabular}

Dependent Variable: CRD

Table A10. Heteroscedasticity tests (source: authors' calculations)

\begin{tabular}{|c|c|c|c|c|c|c|}
\hline \multirow{2}{*}{\multicolumn{2}{|c|}{ Model }} & \multicolumn{2}{|c|}{ Unstandardized Coefficients } & \multirow{3}{*}{$\begin{array}{c}\text { Standardized } \\
\text { Coefficients } \\
\text { Beta }\end{array}$} & \multirow{3}{*}{$\begin{array}{c}\mathrm{t} \\
-7,044\end{array}$} & \multirow{3}{*}{$\begin{array}{l}\text { Sig. } \\
.000 \\
\end{array}$} \\
\hline & & \multirow{2}{*}{$\begin{array}{c}\text { B } \\
-6.980\end{array}$} & \multirow{2}{*}{$\begin{array}{c}\text { Std. Error } \\
.991\end{array}$} & & & \\
\hline \multirow{9}{*}{1} & (Constant) & & & & & \\
\hline & EDU & .138 & .288 & .027 & .478 & .633 \\
\hline & SAC & .450 & .311 & .090 & 1.446 & .149 \\
\hline & MAC & -.008 & .020 & -.024 & -.393 & .695 \\
\hline & $\mathrm{RMC}$ & .533 & .399 & .082 & 1.335 & .183 \\
\hline & AUD & .253 & .286 & .053 & .886 & .377 \\
\hline & STS & -.572 & .350 & -.096 & -1.633 & .103 \\
\hline & AGE & -.222 & .143 & -.089 & -1.546 & .123 \\
\hline & LEV & -.076 & .248 & -.017 & -.305 & .760 \\
\hline
\end{tabular}

Table A11. Summary of tests (source: authors' calculations)

\begin{tabular}{|l|l|l|l|l|}
\hline Model & $\mathrm{R}$ & R Square & Adjusted R Square & Std. Error of the Estimate \\
\hline 1 & $.474^{\mathrm{a}}$ & .225 & .205 & .10339 \\
\hline \multicolumn{2}{|l}{ Predictors: (Constant), LEV, MAC, AGE, EDU, AUD, STS, RMC, SAC } \\
\hline
\end{tabular}


Table A12. Hypotheses testing (source: authors' calculations)

\begin{tabular}{|c|c|c|c|c|c|c|}
\hline & \multirow[t]{2}{*}{ Model } & \multicolumn{2}{|c|}{ Unstandardized Coefficients } & \multirow{2}{*}{$\begin{array}{c}\begin{array}{c}\text { Standardized } \\
\text { Coefficients }\end{array} \\
\text { Beta } \\
\end{array}$} & \multirow[t]{2}{*}{$\mathrm{t}$} & \multirow[t]{2}{*}{ Sig. } \\
\hline & & B & Std. Error & & & \\
\hline \multirow{9}{*}{1} & (Constant) & .137 & .044 & & 3.107 & .002 \\
\hline & EDU & .000 & .013 & .001 & .023 & .981 \\
\hline & SAC & .031 & .014 & .126 & 2.246 & .025 \\
\hline & MAC & .001 & .001 & .035 & .652 & .515 \\
\hline & RMC & .100 & .018 & .310 & 5.640 & .000 \\
\hline & AUD & .033 & .013 & .139 & 2.568 & .011 \\
\hline & STS & -.025 & .016 & -.085 & -1.619 & .107 \\
\hline & AGE & -.020 & .006 & -.165 & -3.182 & .002 \\
\hline & LEV & .012 & .011 & .056 & 1.100 & .272 \\
\hline
\end{tabular}

Table A12. Correlations matrix (source: authors' calculations)

\begin{tabular}{|c|c|c|c|c|c|c|c|c|c|c|}
\hline & & EDU & SAC & MAC & $\mathrm{RMC}$ & AUD & STS & AGE & LEV & CRD \\
\hline \multirow{3}{*}{ EDU } & Pearson Correlation & 1 & .001 & $.249^{* *}$ & $.170^{* *}$ & $.393^{* *}$ & $.211^{* *}$ & -.100 & $-.152^{* *}$ & .057 \\
\hline & Sig. (2-tailed) & & .990 & .000 & .003 & .000 & .000 & .079 & .007 & .316 \\
\hline & $\mathrm{N}$ & 312 & 312 & 312 & 312 & 312 & 312 & 312 & 312 & 312 \\
\hline \multirow{3}{*}{ SAC } & Pearson Correlation & .001 & 1 & -.027 & -.025 & -.008 & .110 & .094 & .030 & .069 \\
\hline & Sig. (2-tailed) & .990 & & .637 & .655 & .895 & .053 & .096 & .603 & .227 \\
\hline & $\mathrm{N}$ & 312 & 312 & 312 & 312 & 312 & 312 & 312 & 312 & 312 \\
\hline \multirow{3}{*}{ MAC } & Pearson Correlation & $.249^{* *}$ & -.027 & 1 & $.302^{* *}$ & $.319^{* *}$ & $.227^{* *}$ & .038 & .080 & -.017 \\
\hline & Sig. (2-tailed) & .000 & .637 & & .000 & .000 & .000 & .498 & .157 & .760 \\
\hline & $\mathrm{N}$ & 312 & 312 & 312 & 312 & 312 & 312 & 312 & 312 & 312 \\
\hline \multirow{3}{*}{$\mathrm{RMC}$} & Pearson Correlation & $.170^{* *}$ & -.025 & $.302^{* *}$ & 1 & $.242^{* *}$ & $.124^{*}$ & -.046 & -.008 & -.013 \\
\hline & Sig. (2-tailed) & .003 & .655 & .000 & & .000 & .028 & .416 & .891 & .825 \\
\hline & $\mathrm{N}$ & 312 & 312 & 312 & 312 & 312 & 312 & 312 & 312 & 312 \\
\hline \multirow{3}{*}{ AUD } & Pearson Correlation & $.393^{* *}$ & -.008 & $.319^{* *}$ & $.242^{* *}$ & 1 & $.232^{* *}$ & -.020 & .008 & .030 \\
\hline & Sig. (2-tailed) & .000 & .895 & .000 & .000 & & .000 & .721 & .887 & .600 \\
\hline & $\mathrm{N}$ & 312 & 312 & 312 & 312 & 312 & 312 & 312 & 312 & 312 \\
\hline \multirow{3}{*}{ STS } & Pearson Correlation & $.211^{* *}$ & .110 & $.227^{* *}$ & $.124^{*}$ & $.232^{* *}$ & 1 & $.180^{* *}$ & .101 & -.019 \\
\hline & Sig. (2-tailed) & .000 & .053 & .000 & .028 & .000 & & .001 & .074 & .744 \\
\hline & $\mathrm{N}$ & 312 & 312 & 312 & 312 & 312 & 312 & 312 & 312 & 312 \\
\hline \multirow{3}{*}{ AGE } & Pearson Correlation & -.100 & .094 & .038 & -.046 & -.020 & $.180^{* *}$ & 1 & $.194^{* *}$ & -.072 \\
\hline & Sig. (2-tailed) & .079 & .096 & .498 & .416 & .721 & .001 & & .001 & .206 \\
\hline & $\mathrm{N}$ & 312 & 312 & 312 & 312 & 312 & 312 & 312 & 312 & 312 \\
\hline \multirow{3}{*}{ LEV } & Pearson Correlation & $-.152^{* *}$ & .030 & .080 & -.008 & .008 & .101 & $.194^{* *}$ & 1 & .057 \\
\hline & Sig. (2-tailed) & .007 & .603 & .157 & .891 & .887 & .074 & .001 & & .317 \\
\hline & $\mathrm{N}$ & 312 & 312 & 312 & 312 & 312 & 312 & 312 & 312 & 312 \\
\hline \multirow{3}{*}{ CRD } & Pearson Correlation & .057 & .069 & -.017 & -.013 & .030 & -.019 & -.072 & .057 & 1 \\
\hline & Sig. (2-tailed) & .316 & .227 & .760 & .825 & .600 & .744 & .206 & .317 & \\
\hline & $\mathrm{N}$ & 312 & 312 & 312 & 312 & 312 & 312 & 312 & 312 & 312 \\
\hline
\end{tabular}

